\title{
Fate of Escherichia coli 0157:H7 and bacterial diversity in corn silage contaminated with the pathogen and treated with chemical or microbial additives
}

\author{
I. M. Ogunade, ${ }^{*}$ Y. Jiang, ${ }^{*}$ D. H. Kim,† A. A. Pech Cervantes, ${ }^{*}$ K. G. Arriola, ${ }^{*}$ D. Vyas, ${ }^{*}$ Z. G. Weinberg, $\ddagger$ \\ K. C. Jeong, ${ }^{*}$ and A. T. Adesogan ${ }^{* 1}$ \\ *Department of Animal Sciences, Institute of Food and Agricultural Sciences, University of Florida, Gainesville 32608 \\ †Division of Applied Life Science (BK21Plus, Institute of Agriculture and Life Science), Gyeongsang National University, Jinju 660-701, \\ South Korea \\ ‡Department of Food Safety and Quality, Agricultural Research Organization, The Volcani Center, Bet Dagan, Israel 50250
}

\section{ABSTRACT}

Inhibiting the growth of Escherichia coli O157:H7 (EC) in feeds may prevent the transmission or cycling of the pathogen on farms. The first objective of this study was to examine if addition of propionic acid or microbial inoculants would inhibit the growth of EC during ensiling, at silo opening, or after aerobic exposure. The second objective was to examine how additives affected the bacterial community composition in corn silage. Corn forage was harvested at approximately $35 \%$ dry matter, chopped to a theoretical length of cut of $10 \mathrm{~mm}$, and ensiled after treatment with one of the following: (1) distilled water (control); (2) $1 \times 10^{5} \mathrm{cfu} / \mathrm{g}$ of EC $(\mathrm{ECCH}) ;(3) \mathrm{EC}$ and $1 \times 10^{6}$ $\mathrm{cfu} / \mathrm{g}$ of Lactobacillus plantarum (ECLP); (4) EC and 1 $\times 10^{6} \mathrm{cfu} / \mathrm{g}$ of Lactobacillus buchneri (ECLB); and (5) $\mathrm{EC}$ and $2.2 \mathrm{~g} / \mathrm{kg}$ (fresh weight basis) of propionic acid, containing $99.5 \%$ of the acid (ECA). Each treatment was ensiled in quadruplicate in laboratory silos for 0 , 3, 7, and $120 \mathrm{~d}$ and analyzed for $\mathrm{EC}, \mathrm{pH}$, and organic acids. Samples from d 0 and 120 were also analyzed for chemical composition. Furthermore, samples from d 120 were analyzed for ammonia $\mathrm{N}$, yeasts and molds, lactic acid bacteria, bacterial community composition, and aerobic stability. The $\mathrm{pH}$ of silages from all treatments decreased below 4 within 3 d of ensiling. Escherichia coli $\mathrm{O} 157: \mathrm{H} 7$ counts were below the detection limit in all silages after $7 \mathrm{~d}$ of ensiling. Treatment with L. buchneri and propionic acid resulted in fewer yeasts and greater aerobic stability compared with control, ECCH, and ECLP silages. Compared with the control, the diversity analysis revealed a less diverse bacterial community in the ECLP silage and greater abundance

Received July 15, 2016.

Accepted November 1, 2016

${ }^{1}$ Corresponding author: adesogan@ufl.edu of Lactobacillus in the ECLP and ECA silages. The ECLB silage also contained greater abundance of Acinetobacter and Weissella than other silages. Subsamples of silages were reinoculated with $5 \times 10^{5} \mathrm{cfu} / \mathrm{g}$ of EC either immediately after silo opening or after $168 \mathrm{~h}$ of aerobic exposure, and EC were enumerated after 6 or $24 \mathrm{~h}$, respectively. All silages reinoculated with EC immediately after silo opening $(120 \mathrm{~h})$ had similar low $\mathrm{pH}$ values $(<4.0)$ and EC counts were below the detection limit. The ECCH and ECLP silages reinoculated with EC after $168 \mathrm{~h}$ of aerobic exposure had relatively high $\mathrm{pH}$ values (>5.0) and $\mathrm{EC}$ counts (5.39 and $5.30 \mathrm{log}$ $\mathrm{cfu} / \mathrm{g}$, respectively) $24 \mathrm{~h}$ later. However, those treated with $L$. buchneri or propionic acid had lower $\mathrm{pH}$ values (4.24 or 3.96, respectively) and lower EC counts (1.32 $\log \mathrm{cfu} / \mathrm{g}$ or none, respectively). During ensiling, EC was eliminated from all silages at $\mathrm{pH}$ below 4.0. During aerobic exposure, the growth of EC was reduced or prevented in silages that had been treated with $L$. buchneri or propionic acid at ensiling, respectively.

Key words: bacterial community, corn silage, Escherichia coli

\section{INTRODUCTION}

Escherichia coli O157:H7 (EC) is a foodborne pathogen that causes various forms of enteritis in humans ranging in severity from bloody diarrhea to hemolytic uremic syndrome and even death (Kaper et al., 2004). This pathogen is implicated in about 100,000 illness cases and 90 deaths annually in the United States (Mead et al., 1999; Scallan et al., 2011). The estimated annual cost associated with EC illnesses can be as high as $\$ 405$ million (Frenzen et al., 2005).

Cattle harbor and shed EC in their manure (Lahti et al., 2003; Mir et al., 2015) and are considered the main reservoirs of the pathogen (Cernicchiaro et al., 2013). Up to $30 \%$ of all cattle are asymptomatic carriers of 
EC (Callaway et al., 2006; Reinstein et al., 2007) and livestock feeds are considered to be the vehicle of transmission among livestock (Hancock et al., 2001; Davis et al., 2003). Corn silage forms the bulk of most dairy cattle rations in the United States and it can be contaminated with EC when untreated manure is used to fertilize corn plants that are subsequently ensiled and fed to cattle or after silo opening via the manure and saliva of cattle (Russell et al., 2000; Keen and Elder, 2002; Smith et al., 2005).

The low $\mathrm{pH}$ achieved during ensiling of corn eliminates pathogenic EC that is present at ensiling (Pedroso et al., 2010; Duniere et al., 2011). At silo opening, aerobic conditions cause increases in $\mathrm{pH}$ (Weinberg et al., 1995) via stimulation of the growth of lactate-utilizing yeasts. The resulting elevated $\mathrm{pH}$ can facilitate growth and spread of EC (Pedroso et al., 2010; Ogunade et al., 2016). In silages contaminated with the pathogen after aerobic exposure, maintenance of a low $\mathrm{pH}$ (below 4.0) due to application of Lactobacillus buchneri at ensiling curtailed the growth of EC (Pedroso et al., 2010). In contrast, Duniere et al. (2011) showed that application of L. buchneri at the time of ensiling did not prevent the growth of EC when aerobically exposed silages were contaminated with a pathogenic EC. Therefore, more studies are needed to ascertain the inhibitory effect of L. buchneri or other additives on EC-contaminated aerobically exposed silage. Such information is critically needed to reduce or prevent cycling of EC among animals and people.

Propionic acid is a strong antifungal agent (Woolford, 1975) that can inhibit the growth of silage yeasts and molds, which are responsible for the rise in $\mathrm{pH}$ of silages during aerobic exposure (Kleinschmit et al., 2005). We hypothesized that by maintaining a low $\mathrm{pH}$ due to inhibition of the growth of lactate-utilizing yeasts that increase the $\mathrm{pH}$ after silo opening, propionic acid would be effective at killing the pathogen during the aerobic phase. To our knowledge, no experiments have examined the use of propionic acid to prevent the growth of EC during or after ensiling. Furthermore, no studies have simultaneously compared the efficacy of inhibiting the growth of EC on silage with propionic acid and obligate or facultative heterofermentative lactic acid bacteria (LAB) inoculants. Therefore, this study was aimed at examining the effectiveness of propionic acid and microbial inoculants containing either L. plantarum or L. buchneri at controlling EC in corn silage during the ensiling and feedout stages.

Most studies that assessed the effects of silage additives on the microbial community composition of silage have been based on culture-based techniques (Ercolini, 2004), real-time PCR (Stevenson et al., 2006), or char- acterization of denaturing gradient gel electrophoresis bands, which all underestimate the microbial community composition (Kraut-Cohen et al., 2016). The application of 454 pyrosequencing has increased our understanding of complex microbial communities (Degnan and Ochman, 2012) such as the rumen. Furthermore, the Illumina MiSeq sequencing system, which gives higher throughput per run, lower error rates, and greater depth and breadth of coverage than the 454 pyrosequencing system, at much lower costs (Degnan and Ochman, 2012; Frey et al., 2014), has enhanced our understanding of microbial communities. A recent study applied a newer sequencing technology, called single molecule real-time sequencing technology, to examine the bacterial profile of alfalfa silage because of its power to generate long sequence reads (Bao et al., 2016); however, this platform suffers from high error rate (Quail et al., 2012). To our knowledge, no studies have used 454 pyrosequencing or Illumina MiSeq sequencing system to examine the silage microbiome. In addition, no studies that examined inhibitory effects of silage additives on pathogens have characterized the microbiome of silage. Therefore, the second objective of this study was to understand how propionate and inoculants affected the bacterial community composition in corn silage using the Illumina sequencing platform.

\section{MATERIALS AND METHODS}

The Biological Safety Office, Division of Environmental Health and Safety, and the Institutional Animal Care and Use Committee of the University of Florida approved all procedures for this study (protocol no. 201408675).

\section{Forage and Treatments}

Whole-plant corn forage (D598R50, Dyna Gro, East Lansing, MI), harvested with a forage chopper (Claas 940, Claas of America Inc., Omaha, NE) at approximately $35 \% \mathrm{DM}$ and chopped to a theoretical length of cut of $10 \mathrm{~mm}$, was treated with the following: (1) distilled water (control); (2) $1 \times 10^{5} \mathrm{cfu} / \mathrm{g}$ EC EDL933 alone $(\mathbf{E C C H}) ;(3) \mathrm{ECCH}+1 \times 10^{6} \mathrm{cfu} / \mathrm{g}$ Lactobacillus plantarum R2014 (ECLP); (4) $\mathrm{ECCH}+1 \times 10^{6}$ cfu/g L. buchneri R1102 (ECLB); and (5) ECCH + $2.2 \mathrm{~g} / \mathrm{kg}$ (fresh weight) of propionic acid, containing 99.5\% of the acid (ECA). Escherichia coli O157:H7 EDL933 was supplied by University of Florida Emerging Pathogens Institute (Gainesville, FL), the silage inoculant bacteria were supplied by Lallemand Animal Nutrition (Milwaukee, WI), and the propionic acid was purchased from Sigma-Aldrich (St. Louis, MO). Bacte- 
rial counts and their viability in the inoculants were verified before silage inoculation by plating on de Man, Rogosa, Sharpe agar (Difco Laboratories Inc., 288210), at $37^{\circ} \mathrm{C}$ for $48 \mathrm{~h}$, and appropriate amounts of the inoculants were added to achieve the desired application rate. The EC was grown on Luria-Bertani (LB; SigmaAldrich, L3022) broth overnight for $18 \mathrm{~h}$ at $35^{\circ} \mathrm{C}$. The next day, the culture was diluted (1:100) in fresh LB broth and again incubated at $37^{\circ} \mathrm{C}$ for $4 \mathrm{~h}$. The cells in the suspension within 16-mm pathlength tubes were adjusted to an optical density of 0.50 at $600 \mathrm{~nm}$ (GENESYS 20 spectrophotometer; Thermo Fisher Scientific-Oxoid Ltd., Basingstoke, UK, 4001-000). Bacterial counts in the suspension were confirmed by direct plating on Sorbitol-MacConkey agar (SMAC; Sigma-Aldrich, 83339) supplemented with cefixime (0.05 mg/L, Sigma-Aldrich, 18588) and potassium tellurite $(2.5 \mathrm{mg} / \mathrm{L}$, Sigma-Aldrich, 60539) to make CTSMAC after incubation at $35^{\circ} \mathrm{C}$ for $24 \mathrm{~h}$. The bacterial inoculants and propionic acid were diluted in distilled water and applied to the forage at $3 \mathrm{~mL} / \mathrm{kg}$ of fresh forage, resulting in application of $1 \times 10^{6} \mathrm{cfu} / \mathrm{g}$ and $2.2 \mathrm{~g} / \mathrm{kg}$ of bacterial inoculants and propionic acid, respectively. Prior to inoculation, the EC suspension was replated on CT-SMAC to ensure accurate application rates. The EC suspension was mixed with $5 \mathrm{~mL}$ of water and applied to the fresh forage at $1 \times 10^{5}$ $\mathrm{cfu} / \mathrm{g}$. Equal quantities of water $(9.5 \mathrm{~mL}$ each) were applied to the treated and control forages. Treatments were applied, using a handheld garden sprayer, to each of quadruplicate samples per treatment separately (1.5 $\mathrm{kg}$ each). Each treated sample was hand-mixed, manually packed into a $14 \times 21 \mathrm{~cm}$, thick-walled plastic bag (International Plastics Inc., Greenville, SC, PB61430), which was vacuumed (Canister Vacuum 4122, Bissell Inc., Grand Rapids, MI) and sealed with silo ties (Uline Corp., Pleasant Prairie, WI, S12356). The silages in the bags were ensiled for 3 and $7 \mathrm{~d}$ at $20^{\circ} \mathrm{C}$ after which subsamples were analyzed for EC, $\mathrm{pH}$, organic acids, and ammonia $\mathrm{N}$. Additionally, $4.5 \mathrm{~kg}$ of the forage was treated with each additive or nothing (control) in quadruplicate and packed into 20-L plastic buckets lined with thick-walled plastic bags and ensiled for $120 \mathrm{~d}$ at ambient temperature $\left(25^{\circ} \mathrm{C}\right)$. Subsamples of these silages were analyzed for $\mathrm{EC}, \mathrm{pH}$, organic acids, ammonia N, LAB, yeast and mold counts, and aerobic stability. Furthermore, subsamples from d 0 and 120 were analyzed for chemical composition.

\section{Survival of E. coli 0157:H7 in Aerobically Exposed Silages}

After the bucket silos were opened on d 120, about $1 \mathrm{~kg}$ of silage from each replicate was transferred to an open-top 20-L plastic bucket, reinoculated with $5 \times 10^{5}$ $\mathrm{cfu} / \mathrm{g}$ of EC and stored at $20^{\circ} \mathrm{C}$ for $24 \mathrm{~h}$. Subsamples were taken after $6,12,18$, and $24 \mathrm{~h}$ to assess changes in EC counts. Furthermore, $2 \mathrm{~kg}$ of silage from each d 120 replicate was placed in a different open-top 20-L plastic bucket. Wireless sensors (Onset Computer Corporation, Cape Cod, MA) that recorded silage temperatures at 30-min intervals were placed in the geometrical center of the silage mass in each bucket. Aerobic stability was defined as the time (h) for the silage temperature to exceed $2.0^{\circ} \mathrm{C}$ above the ambient temperature. After 168 $\mathrm{h}$ of aerobic exposure, silages were reinoculated with 5 $\times 10^{5} \mathrm{cfu} / \mathrm{g}$ of EC on d 127, and $24 \mathrm{~h}$ later (d 128), the population of the pathogen on the silages was counted.

\section{Laboratory Analyses}

Silage subsamples (20 g each) taken on d 120 were diluted with $180 \mathrm{~mL}$ of distilled water and homogenized for $1 \mathrm{~min}$ in a stomacher (UL Lab-Blender 400, Seward Laboratory, London, UK) to obtain silage extracts for further analyses. The suspension was filtered through 2 layers of cheesecloth and immediately analyzed for $\mathrm{pH}$ and counts of EC, LAB, yeasts, and molds. Enumeration of EC was done by serial dilution in buffered peptone water [BPW; peptone $(10 \mathrm{~g} / \mathrm{L})$ and sodium chloride (5 g/L); Thermo Fisher Scientific-Oxoid Ltd., Basingstoke, UK, CM0009] followed by pour plating on duplicate plates of CT-SMAC agar (Zadik et al., 1993). Plates were incubated for $24 \mathrm{~h}$ at $35^{\circ} \mathrm{C}$ and sorbitolnegative colonies were presumptively identified as EC and confirmed by latex agglutination (Thermo Fisher Scientific-Oxoid Ltd., DR0120M; March and Ratnam, 1989). The detection limit for EC counts was $10 \mathrm{cfu} / \mathrm{g}$. An aliquot of the serially diluted extract was also plated on malt extract (Thermo Fisher Scientific-Oxoid, CM0059B) and de Man, Rogosa, Sharpe agars at $32^{\circ} \mathrm{C}$ for 72 and $48 \mathrm{~h}$ for enumeration of yeasts and molds, and $\mathrm{LAB}$, respectively. The $\mathrm{pH}$ of silage extracts was measured using a digital $\mathrm{pH}$ meter (Accumet AB15, Fisher Scientific). For organic acid and ammonia $\mathrm{N}$ analyses, an aliquot of the silage extract was centrifuged at 1,800 $\times g$ for $15 \mathrm{~min}$ at $4^{\circ} \mathrm{C}$. The supernatant was analyzed for ammonia $\mathrm{N}$ using an Auto Analyzer (Technicon, Tarrytown, NY) and an adaptation of the Noel and Hambleton (1976) procedure that involved colorimetric $\mathrm{N}$ quantification, and for organic acids using a High Performance Liquid Chromatograph system (Hitachi L2400, Tokyo, Japan) coupled to a UV detector set at $210 \mathrm{~nm}$ and an Aminex HPX-87H column (Bio-Rad Laboratories, Hercules, CA) with $0.015 M$ sulfuric acid mobile phase and a flow rate of $0.7 \mathrm{~mL} / \mathrm{min}$ at $45^{\circ} \mathrm{C}$. The DM content of the fresh forages and silages was determined by drying samples in a forced-air oven at $55^{\circ} \mathrm{C}$ 
for $48 \mathrm{~h}$. Dried samples were ground to pass the 1-mm screen of a Wiley mill (Thomas Scientific, Swedesboro, NJ). The procedures of Van Soest et al. (1991) were used for NDF and ADF analyses. Heat-stable amylase was used in the NDF analysis but no sodium sulfite was added, and the results were expressed on a DM basis inclusive of residual ash. Crude protein was calculated by multiplying $\mathrm{N}$ measurements obtained from Kjeldahl digestion by 6.25 .

\section{Antibacterial Activity of the Silage Extracts}

Antibacterial activity against EC of the silage extracts was determined by the agar disk diffusion method of Bauer et al. (1966). The EC isolates were cultured in LB broth and adjusted to an optical density of 0.5 at $600 \mathrm{~nm}$ and the inoculum was prepared on CT-SMAC agar. Silage extracts were centrifuged at 5,000 $\times g$ for $30 \mathrm{~min}$ at $4^{\circ} \mathrm{C}$ and the cell-free supernatants were collected. Two sterile cloning discs (6.0-mm diameter; cat. no. 231039, Becton Dickinson Co., Franklin Lakes, $\mathrm{NJ}$ ) were immersed in the supernatants for $20 \mathrm{~s}$ using flame-sterilized forceps and then placed on the surface of CT-SMAC agar plates containing EC. Plates were prepared in duplicate and incubated for $24 \mathrm{~h}$ at $35^{\circ} \mathrm{C}$. The diameters of zones of inhibition around the paper discs were measured with a ruler. In addition, the $\mathrm{pH}$ of the cell-free supernatants of the silage extracts was adjusted to $\mathrm{pH} 5.0$ using $2 \mathrm{~N} \mathrm{NaOH}$ and tested for antibacterial activity against EC.

\section{DNA Extraction and Sequencing}

To understand the influence of EC with or without silage additives on the composition and diversity of the silage microbial community, bacterial diversity analysis of the d 120 silage samples was performed using the Illumina MiSeq platform (Illumina, San Diego, CA). Approximately $100 \mathrm{~g}$ of each sample was added to $200 \mathrm{~mL}$ of PBS $+0.01 \%$ Tween- 80 in a sterile $1-\mathrm{L}$ Erlenmeyer flask. The mixture was sonicated for $45 \mathrm{~min}$ using the Sonicor SC-150 (Sonicor Instrument Corporation, Copiague, NY) followed by centrifugation at 9,000 $\times g$ for 15 min to create a pellet for subsequent DNA extraction.

Total metagenomic DNA was extracted from the resulting pellet using a PowerLyzer PowerSoil DNA isolation kit (MO BIO Laboratories Inc., Carlsbad, CA). Bead beating $(0.1 \mathrm{~mm}$, glass beads; Bullet Blender Storm 24, Averill Park, NY) was used for mechanical disruption of bacterial cells. The purity and concentration of genomic DNA were measured with a spectrophotometer (Nanodrop 115 1000, Thermo Fisher Scientific-
Oxoid Ltd., Basingstoke, UK) and the integrity of DNA was verified by agarose $(0.7 \%)$ gel electrophoresis.

Each replicate sample was prepared for sequencing according to the Illumina $16 \mathrm{~S}$ metagenomic sequencing library protocols to amplify the V3 and V4 regions (Klindworth et al., 2013). The DNA quality was measured by using PicoGreen (Invitrogen, Carlsbad, CA) and Nanodrop (Thermo Scientific, Waltham, MA). Ten nanograms of the genomic DNA was PCR-amplified with the following barcoded fusion primer sequences: 519F (5'-CCTACGGGNGGCWGCAG-3'), 806R (5'-GACTACHVGGGTATCTAATCC-3'). The purified product was quantified using qPCR according to the qPCR Quantification Protocol Guide (KAPA Library Quantification kits for Illumina sequencing platforms, Illumina) and qualified using the LabChip GX HT DNA High-Sensitivity Kit (Perkin Elmer, Waltham, $\mathrm{MA})$. The paired-end $(2 \times 300 \mathrm{bp})$ sequencing was performed by Macrogen Inc. (Seoul, Korea) using the Illumina MiSeq platform (Illumina).

\section{Data and Statistical Analysis}

The experiment had a completely randomized design with 5 treatments and 4 replicates per treatment. All microbial data were transformed to log units and were presented on a wet weight basis. Data were analyzed using the GLIMMIX procedure of SAS (SAS Institute Inc., Cary, NC) and the model for analyzing data collected over time included effects of treatment, day, and treatment $x$ day interaction. When treatment $x$ day interactions were significant, effects of treatment on each day were examined. The model for analyzing data collected at one-time point only included the treatment effect. Means were separated using the Tukey test. Significant differences were declared at $P \leq 0.05$.

For the bacterial community composition data, CDHIT was used for clustering of sequences to identify operational taxonomic units (OTU; Li et al., 2012). The taxonomic composition of each sample was generated using QIIME UCLUST (Edgar, 2010) against the Ribosomal Database Project Release 11 (Cole et al., 2014). Alpha diversity (rarefaction curve for OTU, Chao1, and Shannon indices) and $\beta$ diversity (unweighted principal coordinate analysis UniFrac distance) were generated using the QIIME software package with a script core_diversity_analyses.py (Caporaso et al., 2010). A nonparametric Monte Carlo test was used to compare the within-treatment and between-treatment UniFrac distances. Variables, such as relative abundance of bacteria, number of reads, and species richness and diversity, were analyzed using the GLIMMIX procedure of SAS and a model that included the treatment effect. 
Table 1. Characteristics of whole-plant corn forage inoculated with Escherichia coli O157:H7 (EC) alone or EC and bacterial inoculants or propionic acid before ensiling

\begin{tabular}{|c|c|c|c|c|c|c|c|}
\hline Item & \multicolumn{5}{|c|}{ Treatment $^{1}$} & $\mathrm{SE}$ & $P$-value \\
\hline $\mathrm{pH}$ & $5.94^{\mathrm{a}}$ & $5.99^{\mathrm{a}}$ & $5.93^{\mathrm{a}}$ & $5.93^{\mathrm{a}}$ & $5.14^{\mathrm{b}}$ & 0.04 & 0.01 \\
\hline $\mathrm{CP}(\%$ of $\mathrm{DM})$ & 8.75 & 8.77 & 8.37 & 8.26 & 8.55 & 0.23 & 0.16 \\
\hline $\mathrm{NDF}(\%$ of DM) & 41.6 & 41.4 & 40.6 & 42.5 & 42.4 & 1.40 & 0.68 \\
\hline $\mathrm{ADF}(\%$ of $\mathrm{DM})$ & 24.9 & 24.8 & 25.5 & 25.4 & 25.0 & 1.41 & 0.98 \\
\hline
\end{tabular}

${ }^{\mathrm{ab}}$ Means within a row with different superscripts differ $(P<0.05)$.

${ }^{1}$ Control $=$ distilled water; $\mathrm{ECCH}=1 \times 10^{5} \mathrm{cfu} / \mathrm{g}$ of E. coli O157:H7 (Emerging Pathogen Institute, Gainesville, FL) $\mathrm{ECLP}=\mathrm{ECCH}+1 \times 10^{6}$ $\mathrm{cfu} / \mathrm{g}$ of L. plantarum R2014 (Lallemand Animal Nutrition, Milwaukee, WI); ECLB $=\mathrm{ECCH}+1 \times 10^{6}$ cfu/g of Lactobacillus buchneri R1102 (Lallemand Animal Nutrition); ECA = ECCH $+2.2 \mathrm{~g} / \mathrm{kg}$ of propionic acid (Sigma-Aldrich, St. Louis, MO).

Differences between means were determined using the Tukey test. Significant differences were declared at $P$ $\leq 0.05$.

\section{RESULTS}

\section{Anaerobic Phase}

The DM, CP, NDF, and ADF concentrations of the forage used for each treatment before ensiling were similar and averaged $35.2 \pm 0.44 \%(P=0.75), 8.54 \pm$ 0.23 (\% DM, $P=0.16), 41.7 \pm 0.78$ (\% DM, $P=0.68)$, and $25.1 \pm 0.31$ (\% DM, $P=0.98$; Table 1). The $\mathrm{pH}$ of the ECA corn forage was lower $(P=0.01)$ than those of other silages after the treatments were applied.

After $3 \mathrm{~d}$ of ensiling, all silages had $\mathrm{pH}$ values below the threshold of 4.0. The $\mathrm{pH}$ values remained low for the entire ensiling duration (Figure 1), such that the $\mathrm{pH}$ at final silo opening $(120 \mathrm{~d})$ counts were similar for all silages (Table 2). Escherichia coli O157:H7 was below the detection limit after $3 \mathrm{~d}$ of ensiling in $\mathrm{ECCH}$, ECLP, and ECLB silages, suggesting that it had been eliminated. Although it was detected in the ECA silage on $\mathrm{d} 3$, EC was below the detection limit in all $\mathrm{d} 7$

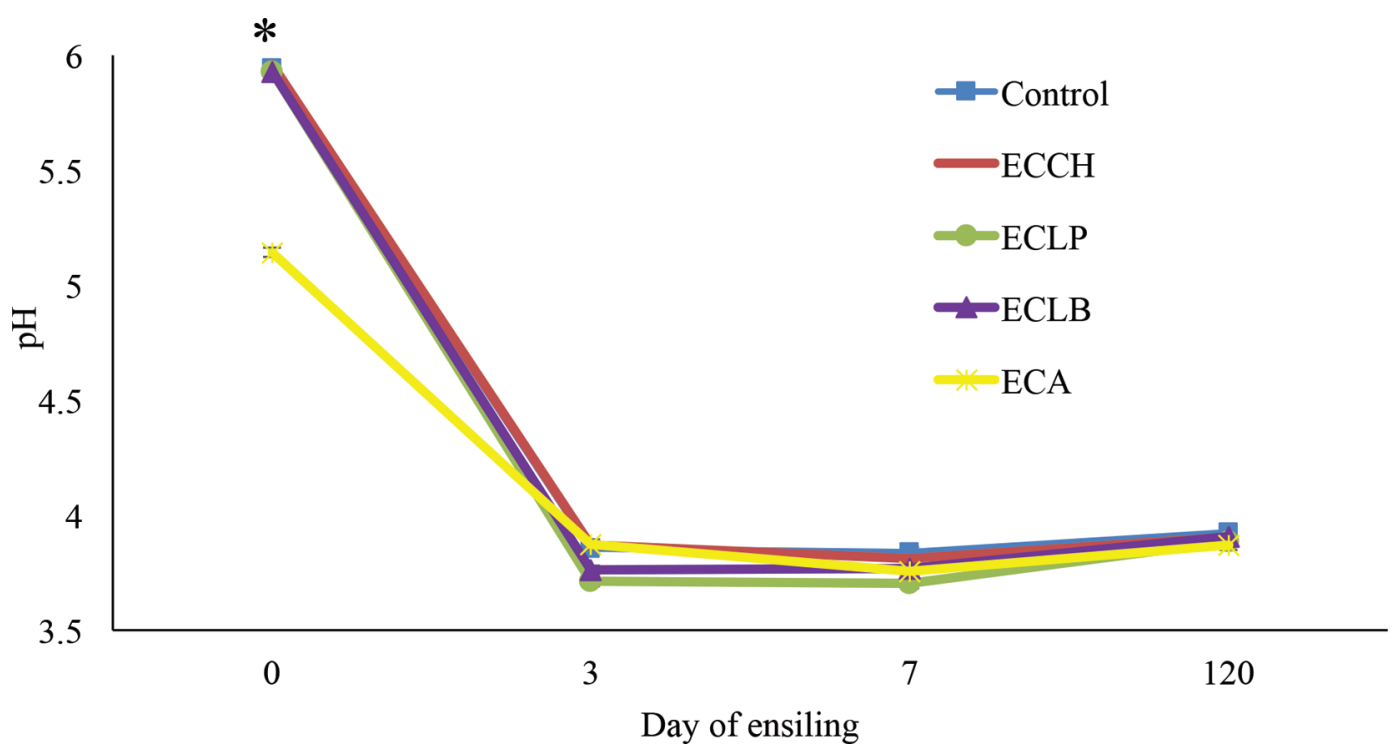

Figure 1. Changes in the $\mathrm{pH}$ of whole-plant corn forage inoculated with $1 \times 10^{5} \mathrm{cfu} / \mathrm{g}$ of Escherichia coli O157:H7 alone or with bacterial inoculants or propionic acid and ensiled for different durations. Control $=$ distilled water; ECCH $=1 \times 10^{5} \mathrm{cfu} / \mathrm{g}$ of $E$. coli O157:H7 (Emerging Pathogen Institute, Gainesville, FL); ECLP $=\mathrm{ECCH}+1 \times 10^{6} \mathrm{cfu} / \mathrm{g}$ of Lactobacillus plantarum R2014 (Lallemand Animal Nutrition, Milwaukee, WI); ECLB $=\mathrm{ECCH}+1 \times 10^{6} \mathrm{cfu} / \mathrm{g}$ of Lactobacillus buchneri R1102 (Lallemand Animal Nutrition); ECA $=\mathrm{ECCH}+2.2 \mathrm{~g} / \mathrm{kg}$ of propionic acid (Sigma-Aldrich, St. Louis, MO). Treatment $\times$ day SE and $P$-value $=0.02$ and 0.001 , respectively; an asterisk $(*)$ indicates that values differed at this ensiling duration $(P<0.05)$. Error bars represent SE. Color version available online. 


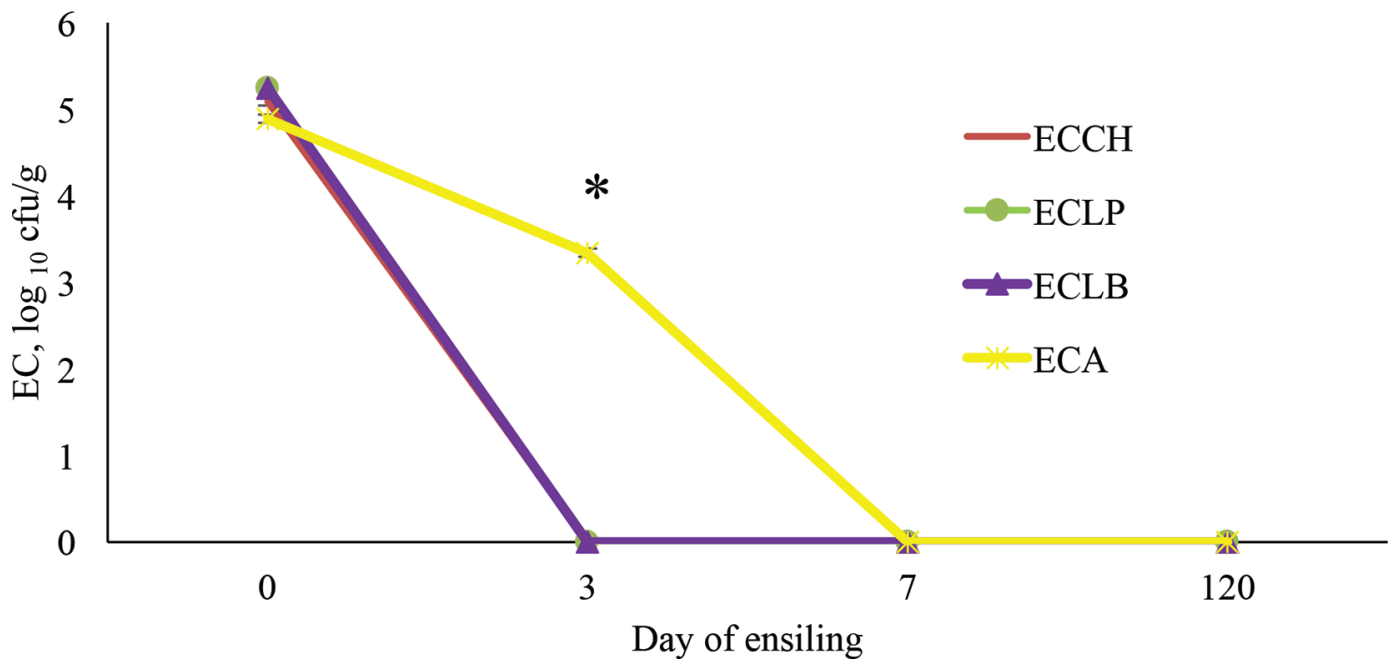

Figure 2. Changes in Escherichia coli O157:H7 (EC) counts of whole-plant corn forage inoculated with $1 \times 10^{5} \mathrm{cfu} / \mathrm{g}$ of EC alone or with bacterial inoculants or propionic acid and ensiled for different durations. Control $=$ distilled water; ECCH $=1 \times 10^{5} \mathrm{cfu} / \mathrm{g}$ of EC $(\mathrm{Emerging}$ Pathogen Institute, Gainesville, FL); ECLP $=\mathrm{ECCH}+1 \times 10^{6} \mathrm{cfu} / \mathrm{g}$ of Lactobacillus plantarum R2014 (Lallemand Animal Nutrition, Milwaukee, WI); ECLB $=\mathrm{ECCH}+1 \times 10^{6} \mathrm{cfu} / \mathrm{g}$ of Lactobacillus buchneri R1102 (Lallemand Animal Nutrition); ECA $=\mathrm{ECCH}+2.2 \mathrm{~g} / \mathrm{kg}$ of propionic acid (Sigma-Aldrich, St. Louis, MO). Treatment $\times$ day SE and $P$-value $=0.05$ and 0.001 , respectively; an asterisk $(*)$ indicates that counts differed at this ensiling duration $(P<0.05)$. Error bars represent $\mathrm{SE}$. Color version available online.

silages (Figure 2), though it is possible that selective enrichment of samples may have led to recovery of EC.

By d 7 of ensiling, the ECLP silage had greater $(P=$ 0.01 ) lactate concentration than other silages (Figure 3); however, at final silo opening (d 120), its lactate concentration was similar to those of control, ECCH, and ECA silages (Table 2). The acetate concentration was similar for all silages at the initial stages of ensiling (on d 3 and 7); however, the concentration was higher in the ECLB silage than other silages at d 120 (Figure 4; Table 2). Propionate was detected only in the ECA silage $(0.41 \% \mathrm{DM})$, reflecting the addition at ensiling, whereas butyrate was not detected in any silage. Ammonia $\mathrm{N}$ concentration was higher $(P<0.05)$ in ECLB silage than ECLP silage at final silo opening. Yeast and mold counts were lower $(P=0.01)$ in the ECLB and ECA d 120 silages (3.43 and $2.92 \mathrm{log} \mathrm{cfu} / \mathrm{g}$, respectively) than in corresponding control, ECCH, and ECLP

Table 2. Fermentation indices and chemical composition and microbial counts of corn silage that was inoculated with Escherichia coli O157:H7 (EC) alone or with bacterial inoculants or propionic acid after $120 \mathrm{~d}$ of ensiling

\begin{tabular}{|c|c|c|c|c|c|c|c|}
\hline Item & \multicolumn{5}{|c|}{ Treatment $^{1}$} & $\mathrm{SE}$ & $P$-value \\
\hline $\mathrm{pH}$ & 3.93 & 3.91 & 3.89 & 3.91 & 3.87 & 0.04 & 0.16 \\
\hline Acetate $(\%$ of DM) & $2.33^{\mathrm{b}}$ & $2.43^{\mathrm{b}}$ & $1.85^{\mathrm{b}}$ & $3.39^{\mathrm{a}}$ & $2.26^{\mathrm{b}}$ & 0.30 & 0.01 \\
\hline Propionate (\% of DM) & $0.00^{\mathrm{b}}$ & $0.00^{\mathrm{b}}$ & $0.00^{\mathrm{b}}$ & $0.00^{\mathrm{b}}$ & $0.41^{\mathrm{a}}$ & 0.05 & 0.01 \\
\hline Yeasts and molds (log cfu/g) & $5.08^{\mathrm{a}}$ & $5.30^{\mathrm{a}}$ & $4.91^{\mathrm{a}}$ & $3.43^{\mathrm{b}}$ & $2.92^{\mathrm{b}}$ & 0.48 & 0.01 \\
\hline $\operatorname{NDF}(\%$ of DM) & 42.5 & 42.3 & 43.3 & 42.5 & 43.3 & 1.89 & 0.97 \\
\hline $\mathrm{ADF}(\%$ of $\mathrm{DM})$ & 28.4 & 28.0 & 28.6 & 28.7 & 28.6 & 1.33 & 0.98 \\
\hline $\mathrm{CP}(\%$ of $\mathrm{DM})$ & 9.58 & 9.11 & 9.23 & 9.02 & 9.37 & 0.21 & 0.11 \\
\hline Ammonia $\mathrm{N}(\%$ of $\mathrm{DM})$ & $0.10^{\mathrm{ab}}$ & $0.10^{\mathrm{ab}}$ & $0.08^{\mathrm{b}}$ & $0.12^{\mathrm{a}}$ & $0.09^{\mathrm{ab}}$ & 0.01 & 0.04 \\
\hline Ammonia $\mathrm{N}(\%$ of total $\mathrm{N})$ & $6.63^{\mathrm{ab}}$ & $7.14^{\mathrm{ab}}$ & $5.20^{\mathrm{b}}$ & $8.41^{\mathrm{a}}$ & $6.23^{\mathrm{ab}}$ & 0.89 & 0.03 \\
\hline
\end{tabular}

${ }^{\mathrm{a}, \mathrm{b}}$ Means within a row with different superscripts differ $(P<0.05)$.

${ }^{1} \mathrm{Control}=$ distilled water; $\mathrm{ECCH}=1 \times 10^{5} \mathrm{cfu} / \mathrm{g}$ of $E$. coli $\mathrm{O} 157: \mathrm{H} 7$ (Emerging Pathogen Institute, Gainesville, FL); ECLP $=\mathrm{ECCH}+1 \times 10^{6}$ cfu/g of L. plantarum R2014 (Lallemand Animal Nutrition, Milwaukee, WI); ECLB = ECCH $+1 \times 10^{6}$ cfu/g of Lactobacillus buchneri R1102 (Lallemand Animal Nutrition); ECA $=\mathrm{ECCH}+2.2 \mathrm{~g} / \mathrm{kg}$ of propionic acid (Sigma-Aldrich, St. Louis, MO). 


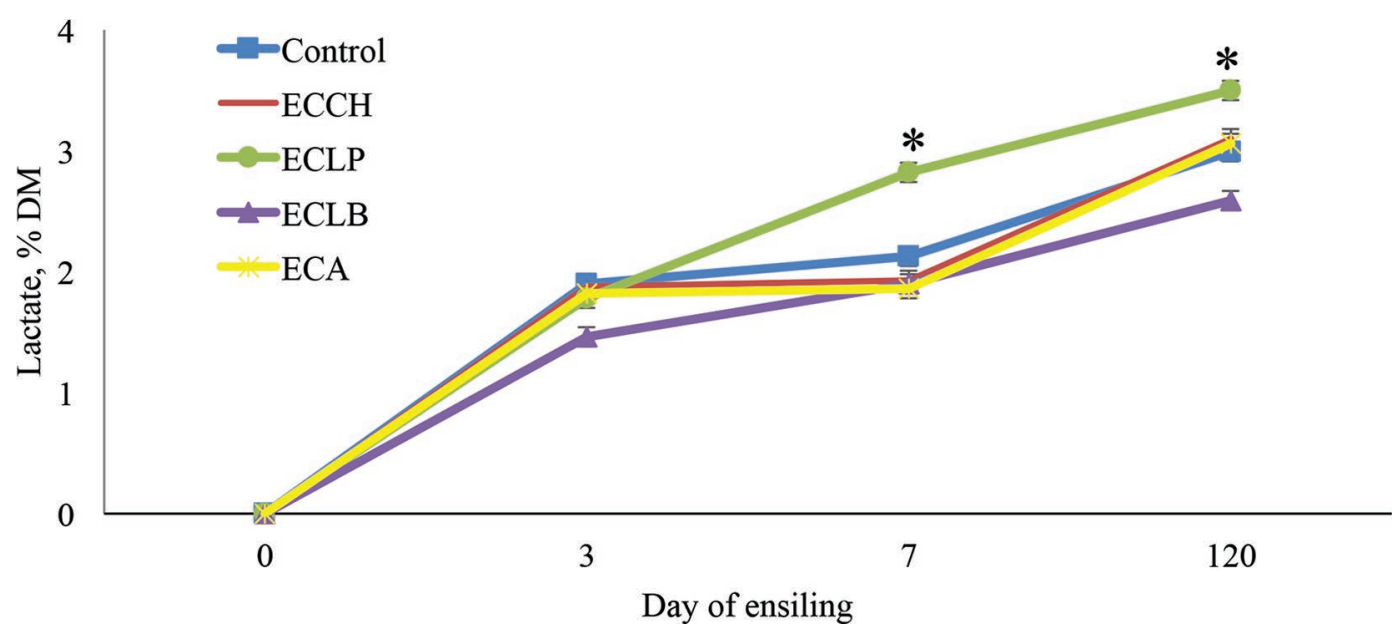

Figure 3. Changes in lactate concentration of whole-plant corn forage inoculated with $1 \times 10^{5} \mathrm{cfu} / \mathrm{g}$ of Escherichia coli O157:H7 alone or with bacterial inoculants or propionic acid and ensiled for different durations. Control = distilled water; $\mathrm{ECCH}=1 \times 10^{5} \mathrm{cfu} / \mathrm{g}$ of $E$. coli O157:H7 (Emerging Pathogen Institute, Gainesville, FL); ECLP = ECCH $+1 \times 10^{6} \mathrm{cfu} / \mathrm{g}$ of Lactobacillus plantarum R2014 (Lallemand Animal Nutrition, Milwaukee, WI); ECLB = ECCH $+1 \times 10^{6} \mathrm{cfu} / \mathrm{g}$ of Lactobacillus buchneri R1102 (Lallemand Animal Nutrition); ECA = ECCH $+2.2 \mathrm{~g} / \mathrm{kg}$ of propionic acid (Sigma-Aldrich, St. Louis, MO). Treatment $\times$ day SE and $P$-value $=0.08$ and 0.001 , respectively; an asterisk $(*)$ indicates that concentrations differed at this ensiling duration $(P<0.05)$. Error bars represent SE. Color version available online.

silages (5.08, 5.30, and $4.91 \mathrm{log} \mathrm{cfu} / \mathrm{g}$, respectively). Lactic acid bacterial counts were unaffected $(P=0.52)$ by treatment.

\section{Aerobic Phase}

Escherichia coli O157:H7 was below the detection limit in silages within $6 \mathrm{~h}$ of reinoculation with the pathogen at silo opening (d 120). Except for the ECA silage, EC was detected on d 128 in all silages that had been reinoculated with the pathogen on d 127 (Figure 5). In addition, the d $128 \mathrm{ECCH}$ and ECLP silages had greater $\mathrm{pH}$ values (5.67 and 6.13 , respectively; $P$ $<0.05)$ and EC counts $(5.39$ and $5.30 \mathrm{log} \mathrm{cfu} / \mathrm{g}$, respectively; $P=0.01$ ) than the ECLB and ECA silages, which had $\mathrm{pH}$ values of 4.24 and 3.96 , and had approximately 10,000-fold lower and no EC, respectively. These responses suggest that the lower $\mathrm{pH}$ of the ECLB

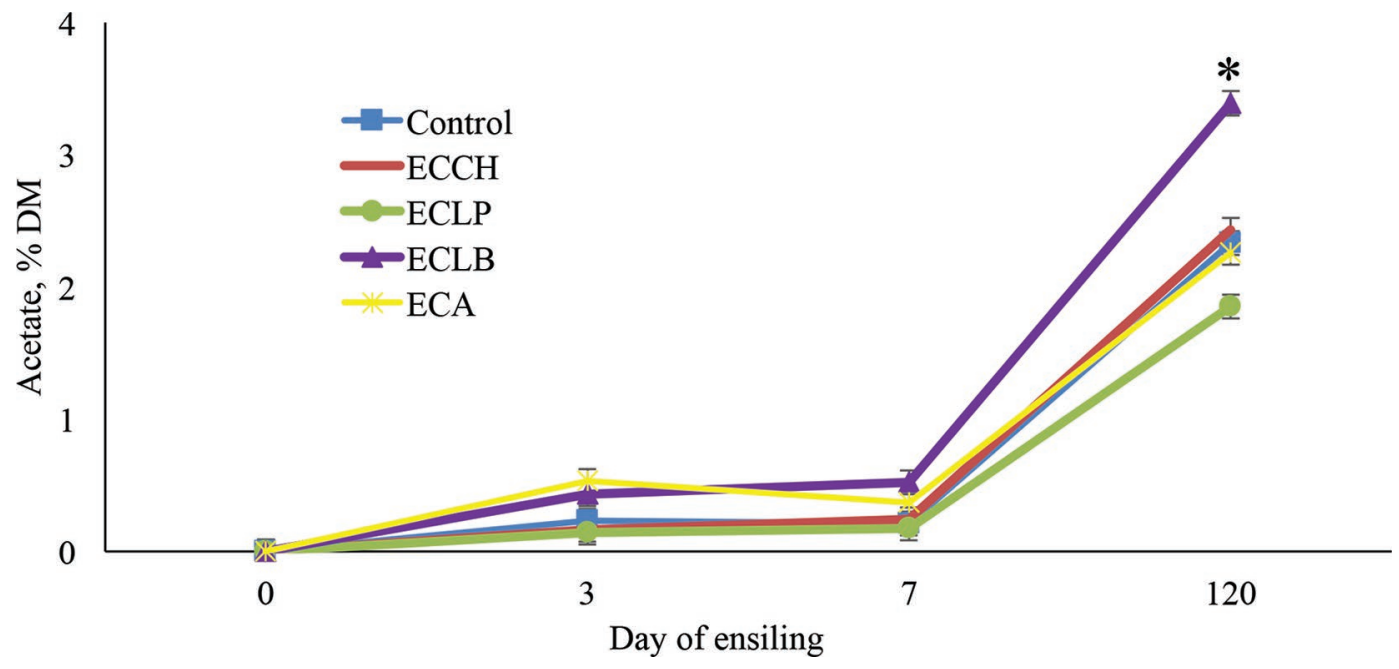

Figure 4. Changes in acetate concentration of whole-plant corn forage inoculated with $1 \times 10^{5} \mathrm{cfu} / \mathrm{g}$ of Escherichia coli O157:H7 alone or with bacterial inoculants or propionic acid and ensiled for different durations. Control = distilled water; $\mathrm{ECCH}=1 \times 10^{5} \mathrm{cfu} / \mathrm{g}$ of $\mathrm{E}$. coli O157:H7 (Emerging Pathogen Institute, Gainesville, FL); ECLP $=\mathrm{ECCH}+1 \times 10^{6} \mathrm{cfu} / \mathrm{g}$ of Lactobacillus plantarum R2014 (Lallemand Animal Nutrition, Milwaukee, WI); ECLB $=\mathrm{ECCH}+1 \times 10^{6} \mathrm{cfu} / \mathrm{g}$ of Lactobacillus buchneri R1102 (Lallemand Animal Nutrition); ECA $=$ ECCH $+2.2 \mathrm{~g} / \mathrm{kg}$ of propionic acid (Sigma-Aldrich, St. Louis, MO). Treatment $\times$ day SE and $P$-value $=0.09$ and 0.001 , respectively; an asterisk $(*)$ indicates that concentrations differed at this ensiling duration $(P<0.05)$. Error bars represent SE. Color version available online. 


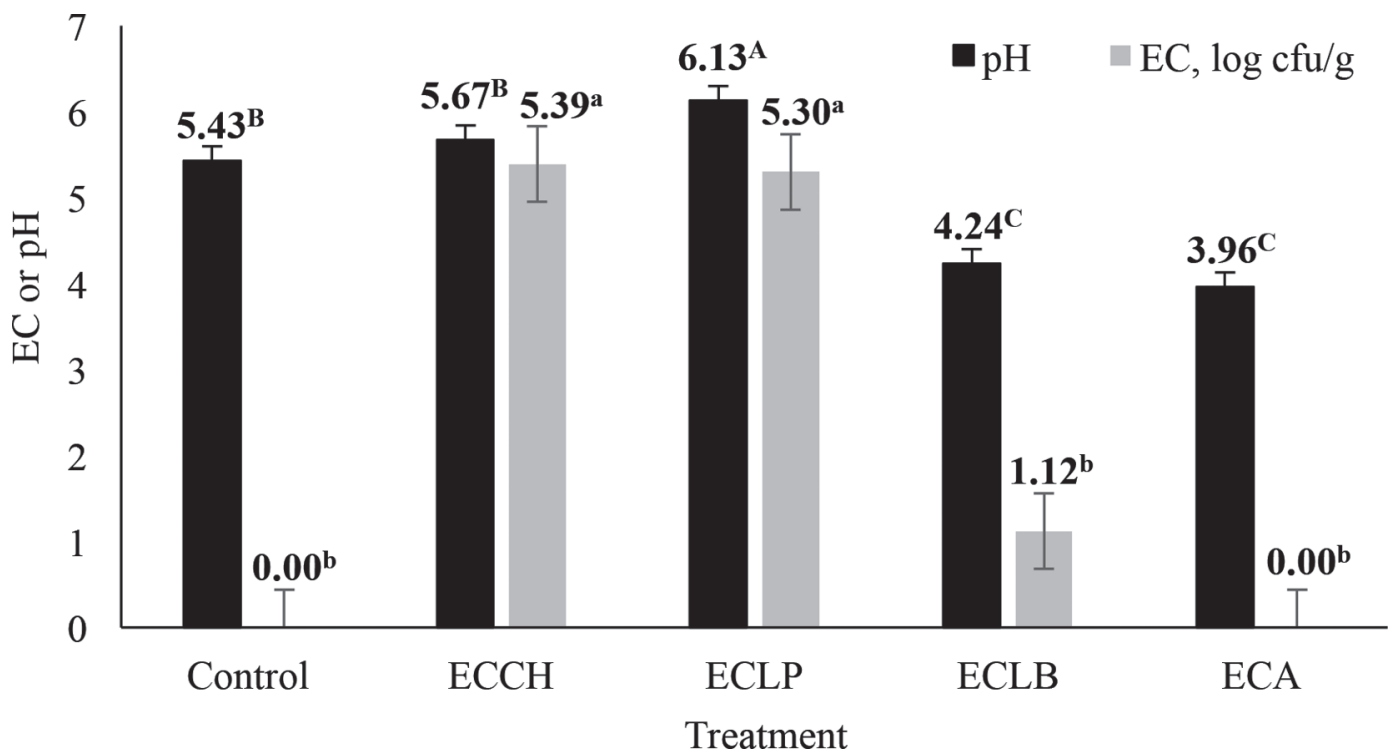

Figure 5. Escherichia coli O157:H7 (EC) counts and pH of whole-plant corn silage (d 128) reinoculated with $5 \times 10^{5}$ cfu/g of EC $168 \mathrm{~h}$ after silo opening. Control $=$ distilled water; $\mathrm{ECCH}=1 \times 10^{5} \mathrm{cfu} / \mathrm{g}$ of EC (Emerging Pathogen Institute, Gainesville, $\left.\mathrm{FL}\right) ; \mathrm{ECLP}=\mathrm{ECCH}+1 \times$ $10^{6} \mathrm{cfu} / \mathrm{g}$ of Lactobacillus plantarum R2014 (Lallemand Animal Nutrition, Milwaukee, WI); ECLB $=\mathrm{ECCH}+1 \times 10^{6} \mathrm{cfu} / \mathrm{g}$ of Lactobacillus buchneri R1102 (Lallemand Animal Nutrition); ECA $=\mathrm{ECCH}+2.2 \mathrm{~g} / \mathrm{kg}$ of propionic acid (Sigma-Aldrich, St. Louis, MO). Similarly shaded bars with different letters differed $(P<0.05)$; SE values for $\mathrm{pH}$ and $\mathrm{EC}=0.17$ and 0.44 , respectively. Error bars represent SE.

and ECA silages prevented the growth of EC, which was facilitated by $\mathrm{pH}$ values that exceeded 5.0. The ECLB and ECA silages also had greater $(P=0.001)$ aerobic stability than control, ECCH, and ECLP silages (Figure 6).

\section{Antibacterial Activity}

The cell-free supernatants from all silage extracts that were not $\mathrm{pH}$-corrected produced a similar zone of inhibition $(4.15 \pm 0.71 \mathrm{~mm})$ against $\mathrm{EC}$, whereas no

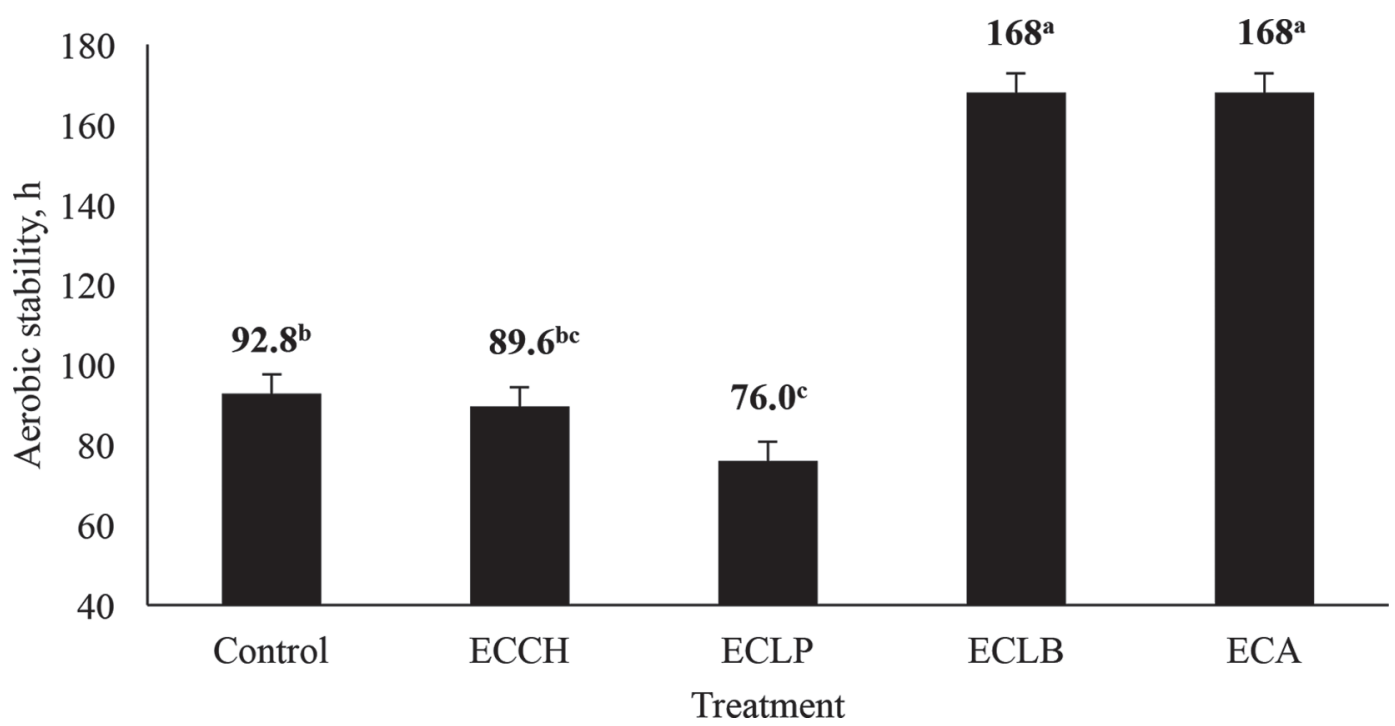

Figure 6. The aerobic stability (h) of whole-plant corn forage inoculated with $1 \times 10^{5} \mathrm{cfu} / \mathrm{g}$ of Escherichia coli O157:H7 alone or with bacterial inoculants or propionic acid and ensiled for $120 \mathrm{~d}$. Control = distilled water; ECCH $=1 \times 10^{5} \mathrm{cfu} / \mathrm{g}$ of E. coli O157:H7 (Emerging Pathogen Institute, Gainesville, FL); ECLP $=\mathrm{ECCH}+1 \times 10^{6} \mathrm{cfu} / \mathrm{g}$ of Lactobacillus plantarum R2014 (Lallemand Animal Nutrition, Milwaukee, WI); $\mathrm{ECLB}=\mathrm{ECCH}+1 \times 10^{6} \mathrm{cfu} / \mathrm{g}$ of Lactobacillus buchneri R1102 (Lallemand Animal Nutrition); ECA $=\mathrm{ECCH}+2.2 \mathrm{~g} / \mathrm{kg}$ of propionic acid (Sigma-Aldrich, St. Louis, MO). Bars with different letters differ $(P<0.05)$. Treatment SE and $P$-value $=4.8$ and 0.001 , respectively. Error bars represent SE. 
Table 3. Bacterial community composition and diversity of whole-plant corn silage inoculated with Escherichia coli O157:H7 alone or with bacterial inoculants or propionic acid ${ }^{1}$

\begin{tabular}{|c|c|c|c|c|c|c|c|}
\hline \multirow[b]{2}{*}{ Item } & \multicolumn{5}{|c|}{ Treatment $^{1}$} & \multirow[b]{2}{*}{$\mathrm{SE}$} & \multirow[b]{2}{*}{$P$-value } \\
\hline & Control & $\mathrm{ECCH}$ & ECLP & ECLB & ECA & & \\
\hline \multicolumn{8}{|c|}{ Species diversity and richness } \\
\hline Shannon index & $0.53^{\mathrm{a}}$ & $0.41^{\mathrm{ab}}$ & $0.30^{\mathrm{b}}$ & $0.52^{\mathrm{a}}$ & $0.42^{\mathrm{ab}}$ & 0.06 & 0.02 \\
\hline Chao index & 33.5 & 26.4 & 22.5 & 28.7 & 32.9 & 4.68 & 0.16 \\
\hline \multicolumn{8}{|l|}{ Phylum (\%) } \\
\hline Firmicutes & $97.8^{\mathrm{bc}}$ & $98.4^{\mathrm{ab}}$ & $99.0^{\mathrm{a}}$ & $97.4^{\mathrm{c}}$ & $98.7^{\mathrm{a}}$ & 0.29 & 0.01 \\
\hline Lactobacillus & $94.9^{\mathrm{cd}}$ & $96.5^{\mathrm{bc}}$ & $98.3^{\mathrm{a}}$ & $94.8^{\mathrm{d}}$ & $97.9^{\mathrm{ab}}$ & 0.54 & 0.01 \\
\hline Sphingobacterium & 0.05 & 0.03 & 0.00 & 0.09 & 0.02 & 0.02 & 0.07 \\
\hline Weissella & $1.57^{\mathrm{b}}$ & $1.42^{\mathrm{b}}$ & $0.72^{\mathrm{c}}$ & $2.39^{\mathrm{a}}$ & $0.79^{\mathrm{c}}$ & 0.20 & 0.01 \\
\hline Acinetobacter & $0.71^{\mathrm{b}}$ & $0.63^{\mathrm{b}}$ & $0.44^{\mathrm{b}}$ & $1.16^{\mathrm{a}}$ & $0.51^{\mathrm{b}}$ & 0.12 & 0.01 \\
\hline Stenotrophomonas & 0.22 & 0.20 & 0.17 & 0.36 & 0.15 & 0.07 & 0.06 \\
\hline Serratia & 0.69 & 0.45 & 0.34 & 0.47 & 0.48 & 0.15 & 0.06 \\
\hline \multicolumn{8}{|c|}{ Lactobacillus species (\%) } \\
\hline
\end{tabular}

${ }^{\mathrm{a}-\mathrm{d}}$ Means within a row with different superscripts differ $(P<0.05)$.

${ }^{1}$ Control $=$ distilled water; ECCH $=1 \times 10^{5} \mathrm{cfu} / \mathrm{g}$ of E. coli O157:H7 (Emerging Pathogen Institute, Gainesville, FL) $; \mathrm{ECLP}=\mathrm{ECCH}+1 \times$ $10^{6} \mathrm{cfu} / \mathrm{g}$ of Lactobacillus plantarum R2014 (Lallemand Animal Nutrition, Milwaukee, WI); ECLB = ECCH $+1 \times 10^{6} \mathrm{cfu} / \mathrm{g}$ of Lactobacillus buchneri R1102 (Lallemand Animal Nutrition); ECA = ECCH $+2.2 \mathrm{~g} / \mathrm{kg}$ of propionic acid (Sigma-Aldrich, St. Louis, MO). Values are averages of 4 replicates of each treatment.

zone was detected for $\mathrm{pH}$-corrected supernatants of the extracts.

\section{Bacterial Community Composition and Diversity}

Sequencing of the V3 to V4 regions of the bacterial $16 \mathrm{~S}$ rRNA gene resulted in 1,250,072 reads, with an average of $62,504 \pm 2,642$ reads per sample after quality filtering. Coverage values were greater than $99 \%$ for all the samples. Rarefaction curves plateaued in all samples sequenced, indicating that the number of reads used in analysis was sufficient for identifying OTU (Supplemental Figure S1; https://doi.org/10.3168/ jds.2016-11745). The unweighted principal coordinate analysis UniFrac plot showed that compositional differences $(P=0.05)$ existed among the bacterial communities of the different silages (Figure 7), and the Monte Carlo test revealed that the between-treatment variation in the unweighted UniFrac distance was greater $(P$ $<0.001)$ than the within-treatment distance. Relative to the control, the ECLP silage resulted in a lower $(P$ $<0.05)$ Shannon index, which measures diversity based on the number and evenness of species (Table 3). The Chao1 index, a measure of the richness of the bacterial species based on number of rare species, was unaffected by treatment (Table 3 ).

Five phyla (Actinobacteria, Bacteroidetes, Cyanobacteria, Firmicutes, and Proteobacteria) were detected in all samples. Firmicutes and Proteobacteria accounted for approximately $99.9 \%$ of the bacterial communities
(Table 3). Relative to the control (97.8\% Firmicutes and $2.07 \%$ Proteobacteria), ECLP and ECA silages had greater $(P<0.05)$ OTU abundance of Firmicutes (99.0 and $98.7 \%$, respectively) and lower abundance of Proteobacteria (0.98 and $1.18 \%$, respectively). It is important to note that sequences that seemed to represent Cyanobacteria may represent chloroplasts from the ensiled corn forage, whose 16S genes have much homology to those of Cyanobacteria (Hanshew et al., 2013).

At the genus level, 6 genera (Lactobacillus, Sphingobacterium, Weissella, Acinetobacter, Stenotrophomonas, Serratia) accounted for approximately $99 \%$ of the bacterial community (Table 3). Compared with the control (94.9\%), ECLP and ECA silages had greater $(P<0.05)$ abundance of Lactobacillus $(98.3$ and $97.8 \%$, respectively). The ECLB silage contained greater $(P<$ 0.01) abundance of Acinetobacter and Weissella (1.16 and $2.39 \%$, respectively) than other silages.

Among the Lactobacillus species, the ECLP silage contained greater $(P<0.05)$ abundance of Lactobacillus diolivorans $(96.8 \%)$ and L. plantarum $(0.98 \%)$ compared with the ECLB silage (93.8 and 0.35\%, respectively).

\section{DISCUSSION}

\section{Anaerobic Phase}

The elimination of EC from the corn silage during the early part of the ensiling phase is largely attributable 


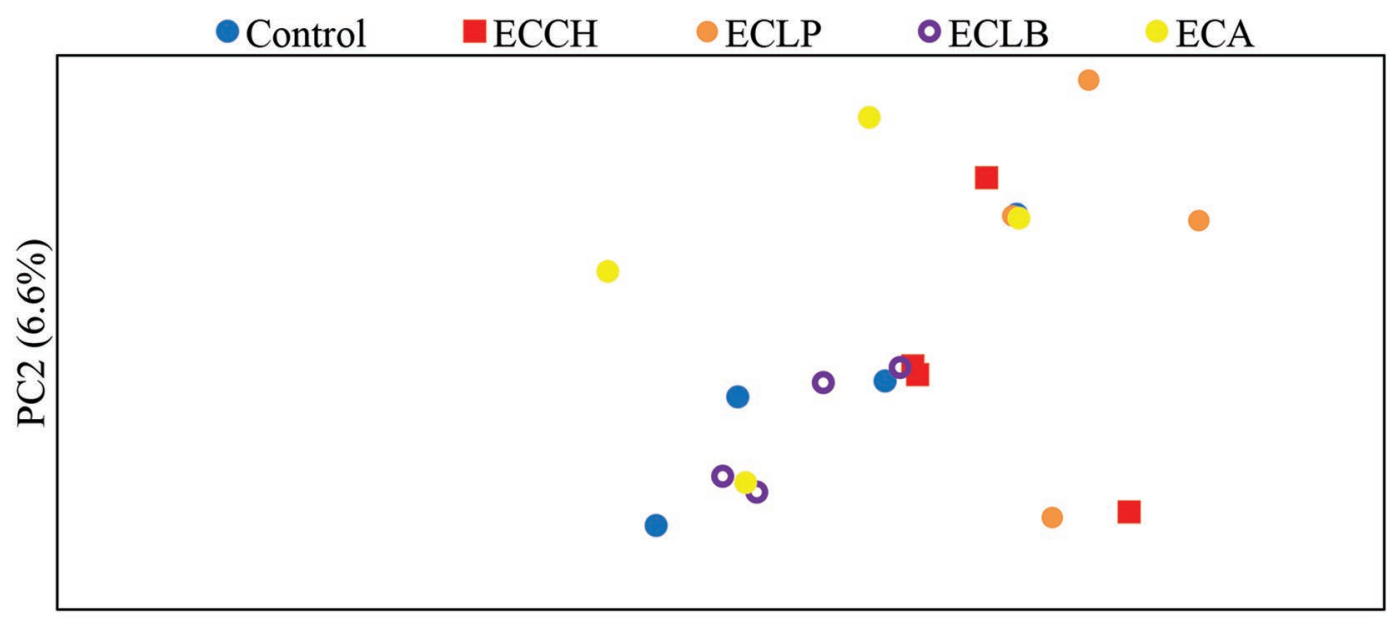

PC1 $(25.5 \%)$

Figure 7. Unweighted UniFrac principal coordinate analysis (PCoA) plot of individual samples in each treatment. Individual samples were represented with dark circles (control), squares $(\mathrm{ECCH})$, medium circles $(\mathrm{ECLP})$, open circles $(\mathrm{ECLB})$, and light circles $(\mathrm{ECA})$. Control $=$ distilled water; $\mathrm{ECCH}=1 \times 10^{5} \mathrm{cfu} / \mathrm{g}$ of E. coli O157:H7 (Emerging Pathogen Institute, Gainesville, FL) $; \mathrm{ECLP}=\mathrm{ECCH}+1 \times 10^{6} \mathrm{cfu} / \mathrm{g}$ of Lactobacillus plantarum R2014 (Lallemand Animal Nutrition, Milwaukee, WI); ECLB = ECCH $+1 \times 10^{6}$ cfu/g of Lactobacillus buchneri R1102 (Lallemand Animal Nutrition); ECA $=\mathrm{ECCH}+2.2 \mathrm{~g} / \mathrm{kg}$ of propionic acid (Sigma-Aldrich, St. Louis, MO). Percentage variation explained by each PCoA is indicated on the axis. Color version available online.

to the low $\mathrm{pH}$ achieved due to rapid accumulation of organic acids. Previous studies have shown that EC was eliminated in corn and barley silages, and alfalfa silage when the $\mathrm{pH}$ was below 4.0 and 5.0, respectively (Bach et al., 2002; Chen et al., 2005; Ogunade et al., 2016). Whereas the disappearance of EC was hastened by microbial inoculation of alfalfa silage because of the slow $\mathrm{pH}$ decline, EC was rapidly eliminated during ensiling of corn, with or without inoculation, because of a rapid drop in pH (Pedroso et al., 2010; Duniere et al., 2011). A microbial inoculant containing Pediococcus pentosaceus and Propionibacterium jensenii also hastened (7 vs. $15 \mathrm{~d}$ ) the elimination of EC in barley silages due to a relatively slow pH decline (Bach et al., 2002).

Although antibacterial activity against EC was evident in the low $\mathrm{pH}$ silage extracts, it was not observed in the $\mathrm{pH}$-corrected extracts. This supports the notion that the elimination of EC during ensiling is most probably due to inhibitory effect of the low $\mathrm{pH}$. Nevertheless, the $\mathrm{pK}_{\mathrm{a}}$ (acid dissociation constant) may also be implicated because at low $\mathrm{pH}$, organic acids are mostly in protonated states, and the protons can diffuse into bacterial cells and cause cell death (Bjornsdottir et al., 2006). Previous studies have shown that antibacterial activity was not detected in extracts of inoculant-treated alfalfa and corn silages adjusted to $\mathrm{pH} 5.5$ and 5.0, respectively, whereas the $\mathrm{pH}$-corrected cell-free supernatants from pure cultures of inoculant bacteria showed activity against EC (Pedroso et al., 2010; Ogunade et al., 2016). Gollop et al. (2005) re- ported that pure cultures of L. plantarum, Enterococcus faecium, and L. buchneri inhibited the growth of $M i$ crococcus luteus and Pseudomonas aeruginosa, but very few of the extracts of silages treated with these bacteria showed activity independent of $\mathrm{pH}$.

More time $(7 \mathrm{~d})$ was required for elimination of $\mathrm{EC}$ in ECA silages than in others probably because of the lower initial pH of the ECA silage before ensiling. Goodson and Rowbury (1989) reported that E. coli strains that were previously habituated in a medium with a $\mathrm{pH}$ of 5.0 survived longer after short periods of exposure to $\mathrm{pH}$ 3.5, whereas those that were previously habituated in a medium with a $\mathrm{pH}$ of 7 failed to grow. Likewise, strains of EC habituated in a sub-lethal medium with a $\mathrm{pH}$ of 5.0 had greater resistance than those habituated in a medium with higher $\mathrm{pH}$ values when they were subsequently exposed to a medium with an acidic $\mathrm{pH}$ of 3.85 (Leyer et al., 1995). Similarly, in this study, EC persisted longer in the ECA silage than in other silages and the respective $\mathrm{pH}$ values were 5.14 and $5.95 \pm 0.03$ at ensiling (Table 1).

Addition of L. buchneri to silage enhances anaerobic degradation of lactate to acetate (Oude Elferink et al., 2001; Kleinschmit and Kung, 2006; Queiroz et al., 2013). In accordance, in this study, silage inoculation with $L$. buchneri increased the concentration of acetate. The antimycotic properties of acetate (Danner et al., 2003; Schmidt and Kung, 2010) and propionate (Woolford, 1975) resulted in the lower yeast counts of ECLB and ECA silages, respectively, compared with those 
in the other silages. Lactobacillus buchneri-inoculated silage had higher ammonia $\mathrm{N}$ concentration compared with ECLP silage. This agrees with previous studies on corn and sorghum silages (Driehuis et al., 2001; Filya, 2003). A high concentration of ammonia N (>10\% of total $\mathrm{N}$ ) in corn silage is a marker of excessive protein breakdown (Ward, 2008), typically caused by a slow drop in $\mathrm{pH}$ and or clostridial fermentation (Kung and Shaver, 2001). However, the concentrations observed in these silages are within the range for well-preserved corn silage (Ward, 2008). Also, the fact that no butyrate was detected supports the deduction that spoilage due to clostridial fermentation was not evident.

\section{Aerobic Postensiling Phase}

This aspect of the experiment was conducted to determine whether treatment with the silage additives at ensiling would enhance the aerobic stability of the silages and inhibit the growth of EC in silages contaminated at silo opening (d 120) and after $168 \mathrm{~h}$ of aerobic exposure (d 127). The elimination of EC within $6 \mathrm{~h}$ of reinoculation and aerobic exposure in all silages on $\mathrm{d}$ 120 is probably because the low $\mathrm{pH}$ value $(3.93 \pm 0.04)$ prevented their survival. Bach et al. (2002) reported that EC was not detected in barley silage $24 \mathrm{~h}$ after reinoculation of the pathogen at silo opening because the $\mathrm{pH}$ value of the silage was below 4.0. Likewise, EC was not detected in corn silage after $24 \mathrm{~h}$ of reinoculation at silo opening (Pedroso et al., 2010) because the $\mathrm{pH}$ values of the silages were still below 4.0.

The inhibitory effects of acetate and propionate on spoilage-causing fungi (Ranjit et al., 2002; Kleinschmit et al., 2005) in silages treated with L. buchneri and propionic acid are responsible for the greater aerobic stability of such silages. Aerobic spoilage occurs due to degradation of lactic acid by lactate-utilizing yeasts in the presence of air (Pahlow et al., 2003; Kung, 2010). A meta-analysis showed that L. buchneri inoculation decreased yeast counts and improved aerobic stability of corn silages (Kleinschmit and Kung, 2006). Similarly, in 3 separate experiments, addition of propionic acidbased products to corn silages at $0.2 \%$ of fresh weight improved the aerobic stability of the silages (Kung et al., 1998).

Whereas no or low counts of EC were detected in ECA and ECLB silages reinoculated with the pathogen after $168 \mathrm{~h}$ of aerobic exposure, high counts were detected in ECCH and ECLP silages probably due to their higher $\mathrm{pH}$ values $(\mathrm{pH}>5)$ compared with those of the other silages. Previous studies have shown that EC grows well in corn silage with $\mathrm{pH}$ above 4.0 (Fenlon and Wilson, 2000; Pedroso et al., 2010; Duniere et al.,
2011), whereas its growth is curtailed by additives that keep the silage $\mathrm{pH}$ below 4.0 after silo opening (Pedroso et al., 2010; Duniere et al., 2011). Likewise, our results showed that keeping the silage $\mathrm{pH}$ below 4 after aerobic exposure improved the silage shelf-life and also helped to curtail or prevent the growth and spread of EC. This indicates that keeping the corn silage $\mathrm{pH}$ below 4.0 during the feedout stage with appropriate silage additives may help reduce the risk of survival and prevalence of $\mathrm{EC}$ or other low pH-sensitive pathogens in aerobically exposed silages. Nevertheless, aerobically stable silage may permit survival of EC that contaminates the silage during the aerobic exposure phase, as shown in this study and our previous study on alfalfa silage (Ogunade et al., 2016).

\section{Bacterial Community Composition and Diversity}

Principal coordinate analysis of diversity based on UniFrac (unweighted) distances indicates compositional differences based on the presence or absence of OTU among samples (Park et al., 2016). The fact the bacterial diversity and taxonomic composition of the ECCH silage did not differ from that of the control silage suggests that the microbiome shift observed in the ECLP, ECLB, and ECA silages reflect the effects of the respective additives alone. Notable features of such microbiomes were greater abundance of Lactobacillus in ECLP and ECA silages, and greater abundances of Acinetobacter and Weissella in ECLB silage compared with the control silage. Studies that used the denaturing gradient gel electrophoresis technique reported little or no change in the bacterial community structure of corn silage treated with $L$. buchneri, L. plantarum, or Lactobacillus rhamnosus (Li and Nishino, 2011; Santos et al., 2016).

The taxonomic classification of lactobacilli to the species level with $16 \mathrm{~S}$ gene sequences may sometimes misrepresent the microbial population due to the relatively little sequence diversity among lactobacilli (Berthier and Elrhich, 1998; Felis and Dellaglio, 2007). This may partly explain the unexpected low abundance of L. plantarum in ECLP silage, absence of $L$. buchneri in ECLB silage, and high abundance of $L$. diolivorans in all silages. Pang et al. (2011) identified Weissella cibaria and Weissella confusa as the dominant bacterial species in corn silage, L. plantarum as the dominant species in sorghum and rice silages, and Leuconostoc pseudomesenteroides, Lactobacillus paraplantarum, and L. plantarum as the dominant species in alfalfa silage. A recent study that applied 16S ribosomal RNA gene amplicon sequencing revealed that $99 \%$ of the sequence reads detected were Lactobacillus reuteri 
and Lactobacillus pontis in corn, sorghum, and wheat silages (Kraut-Cohen et al., 2016). Lactobacillus reuteri and L. pontis have previously been detected in silages, but had never been identified as dominant bacteria $(\mathrm{Li}$ and Nishino, 2011; Wu et al., 2014). These dominance reports are also likely to be affected by the ensiling duration or time of sampling, which is known to influence the bacterial community of silage (Beck, 1972; Graf et al., 2016).

Lactobacillus diolivorans, which phylogenetically belongs to L. buchneri group, has previously been isolated from corn silage (Krooneman et al., 2002), but we found no study that attempted to quantify the abundance of the bacterium in silage. This bacterium is not regarded as a dominant Lactobacillus species in silage (Krooneman et al., 2002), but it can degrade 1,2-propanediol, a fermentation product of $L$. buchneri, to 1-propanol and propionic acid (Krooneman et al., 2002). In corn silage treated with $L$. diolivorans alone or with $L$. buchneri, no 1-propanol or propionate was detected, and the authors suggested that $L$. diolivorans converted 1,2-propanediol that was present into an unknown intermediate compound (Charley and Kung, 2005). In contrast, Zhang et al. (2010) reported that a higher concentration of propionate was formed when $L$. diolivorans was grown with 1,2-propanediol as the sole carbon source than when it was grown with 1,2-propanediol, fructose, and maltose in sourdough. Neither 1,2-propanediol nor 1-propanol was measured in this study and propionate was only detected in ECA silage due to treatment with propionic acid at ensiling. Therefore, no conclusive deductions can be drawn about the presence or role of $L$. diolivorans in the silages. More research is needed to confirm the dominance of $L$. diolivorans in corn silage and to elucidate its role. Such studies should consider other approaches for characterizing the microbial community. For instance, previous studies showed that recA gene sequences are more precise than $16 \mathrm{~S}$ rRNA for differentiation of LAB species in mixed culture (Felis et al., 2001; Torriani et al., 2001). Furthermore, recent studies claimed that the Pacific Biosciences single molecule, real-time sequencing technology can predict the bacterial profile of target samples to species level because of its power to generate long sequence reads (Zhang et al., 2015; Bao et al., 2016).

The low bacterial diversity observed in this study, as shown by the low Shannon index $(0.44 \pm 0.09)$, is as a result of the high abundance $(96.5 \pm 1.63 \%)$ of Lactobacillus species due to the low $\mathrm{pH}$ value of corn silage $(<4.0)$. The more the abundance of a dominant bacterium, the less diverse the microbial community (Polley et al., 2007; Allen et al., 2009).
In this study, we detected 2 genera, Weissella and Acinetobacter, whose roles in corn silage have not been extensively studied. Bacteria assigned to genus Weissella are strictly heterofermentative, producing a mixture of lactate and acetate as the major end products of sugar metabolism (Fusco et al., 2015; Graf et al., 2016). Inoculation of alfalfa silage with heterofermentative LAB strain, Weissella paramesenteroides, resulted in increased acetate concentration (Cai et al., 1998). In addition, lactate and acetate are the major acids produced by $W$. confusa during fermentation of rice cake (Baek et al., 2012). Furthermore, Ndagano et al. (2011) reported the production of acetate as well as other antifungal compounds, such as 3-hydroxy fatty acids and phenyllactate, by $W$. paramesenteroides isolated from fermented cassava (Manihot esculenta). Other silages contained equal or greater abundance of Lactobacillus, which also produce lactate and acetate (Charley and Kung, 2005), and no other bacteria that are known to produce lactate or acetate responded to the inoculant treatments. Thus, the greater abundance of Weissella in the ECLB silage may partly explain its greater acetate concentration and greater aerobic stability relative to other silages except ECA. Nevertheless, it is noteworthy that the abundance of Weissella was relatively small $(\geq 2.39 \%)$. Future studies should characterize the antifungal compounds produced by lactic acid bacteria belonging to genus Weissella and examine their effects on the fermentation and aerobic stability of corn silage.

Acinetobacter species are aerobic, nonfermenting bacteria, which can be found in different environments (Kämpfer and Glaeser, 2012) but are supposedly absent in silage (Li and Nishino, 2011). Some Acinetobacter species can survive in an anaerobic environment in the presence of acetate as a substrate (Fuhs and Chen, 1975). The uptake of acetate by Acinetobacter in an anaerobic condition requires energy from carbohydrate degradation (Satoh et al., 1996). Silage DM loss during ensiling is typically caused by silage decay as a result of depletion of forage carbohydrate mass by activities of aerobic microorganisms at the initial stage of ensiling (Pitt, 1986). Aerobic respiration uses readily available carbohydrates and produces heat and the consequent silage DM and energy losses during ensiling (Muck and Holmes, 2000). The increased abundance of Acinetobacter in ECLB silage may have resulted from the increased acetate concentration, and this may partly explain the small, though important, DM losses sometimes observed in silages that had been treated with L. buchneri at ensiling (Filya, 2003; Kleinschmit and Kung, 2006). The practical significance of the seemingly small statistical differences (0.71 vs. $1.16 \%$ ) in 
the abundance of Acinetobacter is unknown. Future studies should examine if Acinetobacter is responsible for some or all of the DM losses that occur in silages that were treated with L. buchneri at ensiling. The abundances of unknown or unculturable bacteria that were not described were either too low $(<0.01 \%)$ or did not respond to silage treatment.

\section{CONCLUSIONS}

This study showed that when the $\mathrm{pH}$ dropped below 4.0 within $3 \mathrm{~d}$ of ensiling, EC counts were below the detection limit of $10 \mathrm{cfu} / \mathrm{g}$ in all silages contaminated at ensiling with $1 \times 10^{5} \mathrm{cfu} / \mathrm{g}$ of the pathogen. The exception was the ECA silage, which required $7 \mathrm{~d}$ of ensiling for elimination of EC, likely because of habituation of EC to acidic conditions when the forage was treated with propionic acid. Application of $L$. buchneri and propionic acid reduced yeast counts, improved aerobic stability, and maintained a low $\mathrm{pH}$ for the entire duration of aerobic exposure. Reinoculation of silages with EC after $168 \mathrm{~h}$ of aerobic exposure resulted in relatively high EC counts of 5.39 and $5.30 \mathrm{cfu} / \mathrm{g}$ in ECCH and ECLP silages, respectively, whereas the pathogen was 10,000-fold lower in ECLB silage, which had a pH of 4.24, and it was below the detection limit in the ECA silage, which had a $\mathrm{pH}$ 3.96. This suggests that maintenance of $\mathrm{pH}$ of approximately 4.0 or lower with additives can curtail or prevent the growth of EC in contaminated aerobically exposed silages, and inhibit cycling of EC on farms or limit its introduction into the food chain. The fact that extracts of d 120 silages exhibited activity against EC before but not after they were $\mathrm{pH}$ adjusted, confirms that EC elimination from the silages was mediated by low silage $\mathrm{pH}$. Bacterial diversity analysis of the silage revealed that the bacterial community composition in the silages was modified by additive treatment. Our results revealed that $98.3 \pm 0.65 \%$ of the bacterial community involved in lactic acid fermentation in corn silage belong to phylum Firmicutes and $96.5 \pm 1.63 \%$ belong to genus Lactobacillus. Furthermore, the potential respective roles in corn silage fermentation and DM losses of Weissella and Acinetobacter should be determined because their abundances increased with inoculation with $L$. buchneri.

\section{ACKNOWLEDGMENTS}

The authors gratefully acknowledge funding for this project from BARD (United States-284 Israel Binational Agricultural Research and Development Fund),
Project IS-4704-14. We are grateful to Lallemand Animal Nutrition for donation of microbial additives.

\section{REFERENCES}

Allen, B., M. Kon, and Y. Bar-Yam. 2009. A new phylogenetic diversity measure generalizing the Shannon index and its application to phyllostomid bats. Am. Nat. 174:236-243.

Bach, S. J., T. A. McAllister, J. Baah, L. J. Yanke, D. M. Veira, V. P. J. Gannon, and R. A. Holley. 2002. Persistence of Escherichia coli O157:H7 in barley silage: Effect of a bacterial inoculant. J. Appl. Microbiol. 93:288-294.

Baek, E., H. Kim, H. Choi, S. Yoon, and J. Kim. 2012. Antifungal activity of Leuconostoc citreum and Weissella confusa in rice cakes. J. Microbiol. 50:842-848.

Bao, W., Z. Mi, H. Xu, Y. Zheng, L. Y. Kwok, H. Zhang, and W. Zhang. 2016. Assessing quality of Medicago sativa silage by monitoring bacterial composition with single molecule, real-time sequencing technology and various physiological parameters. Sci. Rep. 6:28358. https://doi.org/10.1038/srep28358.

Bauer, A. W., M. W. Kirby, J. C. Sherris, and M. Turck. 1966. Antibiotic susceptibility testing by a standardized single disk method. Am. J. Clin. Pathol. 45:493-496.

Beck, T. 1972. The quantitative and qualitative composition of the lactic acid bacteria population in silage. Landwirtschaftliche Forschung 27:55-63.

Berthier, F., and S. D. Elrhich. 1998. Rapid species identification within two groups of closely related lactobacilli using PCR primers that target the $16 \mathrm{~S}-23 \mathrm{~S}$ rRNA spacer region. FEMS Microbiol. Lett. 161:97-106.

Bjornsdottir, K., F. Breidit Jr., and R. F. McFeeters. 2006. Protective effect of organic acids on survival of Escherichia coli O157:H7 in acidic environments. Appl. Environ. Microbiol. 72:660-664.

Cai, Y., Y. Benno, M. Ogawa, S. Ohmomo, S. Kumai, and T. Nakase. 1998. Influence of Lactobacillus species from an inoculant and of Weissella and Leuconostoc species from forage crops on silage fermentation. Appl. Environ. Microbiol. 64:2982-2987.

Callaway, T. R., T. S. Edrington, A. D. Brabban, J. E. Keen, R. C. Anderson, M. L. Rossman, M. J. Engler, K. J. Genovese, B. L. Gwartney, J. O. Reagan, T. L. Poole, R. B. Harvey, E. M. Kutter, and D. J. Nisbet. 2006. Fecal prevalence of Escherichia coli O157, Salmonella, Listeria, and bacteriophage infecting E. coli O157:H7 in feedlot cattle in the southern plains region of the United States. Foodborne Pathog. Dis. 3:234-244.

Caporaso, J. G., J. Kuczynski, J. Stombaugh, K. Bittinger, F. D Bushman, E. K. Costello, N. Fierer, P. A. Gonzalez, J. K. Goodrich, J. I. Gordon, G. A. Huttley, S. T. Kelley, D. Knights, J. E. Koenig, R. E. Ley, C. A. Lozupone, D. McDonald, B. D. Muegge, M. Pirrung, J. Reeder, J. R. Sevinsky, P. J. Turnbaugh, W. A. Walters, J. Widmann, T. Yatsunenko, J. Zaneveld, and R. Knight. 2010. QIIME allows analysis of high-throughput community sequencing data. Nat. Methods 7:335-336.

Cernicchiaro, N., C. A. Cull, Z. D. Paddock, X. Shi, J. Bai, T. G. Nagaraja, and D. G. Renter. 2013. Prevalence of shiga toxin-producing Escherichia coli and associated virulence genes in feces of commercial feedlot cattle. Foodborne Pathog. Dis. 10:835-841.

Charley, R. C., and L. Kung Jr. 2005. Treatment of silage with Lactobacillus diolivorans. Lallemand Animal Nutrition North America, assignee. US Pat. No. 20050281917.

Chen, Y., S. Sela, M. Gamburg, R. Pinto, and Z. G. Weinberg. 2005 Fate of Escherichia coli during ensiling of wheat and corn. Appl. Environ. Microbiol. 71:5163-5170.

Cole, J. R., Q. Wang, J. A. Fish, B. Chai, D. M. McGarrell, Y. Sun, C. T. Brown, A. Porras-Alfaro, C. R. Kuske, and J. M. Tiedje. 2014 Ribosomal Database Project: Data and tools for high throughput rRNA analysis. Nucleic Acids Res. 42:D633-D642.

Danner, H., M. Holzer, E. Mayrhuber, and R. Braun. 2003. Acetic acid increases stability of silage under aerobic conditions. Appl. Environ. Microbiol. 69:562-567. 
Davis, M. A., D. D. Hancock, D. H. Rice, D. R. Call, R. Digiacomo, M. Samadpour, and T. E. Besser. 2003. Feedstuffs as a vehicle of cattle exposure to Escherichia coli O157:H7 and Salmonella enterica. Vet. Microbiol. 95:199-210.

Degnan, P. H., and H. Ochman. 2012. Illumina-based analysis of microbial community diversity. ISME J. 6:183-194.

Driehuis, F., S. J. W. H. Oude Elferink, and P. G. Van Wikselaar. 2001. Fermentation characteristics and aerobic stability of grass silage inoculated with Lactobacillus buchneri, with or without homofermentative lactic acid bacteria. Grass Forage Sci. 56:330-343.

Duniere, L., A. Gleizal, F. Chaucheyras-Durand, I. Chevallier, and D. Thevenot-Sergentet. 2011. Fate of Escherichia coli O26 in corn silage experimentally contaminated at ensiling, at opening or after aerobic exposure and protective effect of various bacterial inoculants. Appl. Environ. Microbiol. 77:8696-8704.

Edgar, R. C. 2010. Search and clustering orders of magnitude faster than BLAST. Bioinformatics 26:2460-2461.

Ercolini, D. 2004. PCR-DGGE fingerprinting: Novel strategies for detection of microbes in food. J. Microbiol. Methods 56:297-314.

Felis, G. E., and R. Dellaglio. 2007. Taxonomy of lactobacilli and bifidobacteria. Curr. Issues Intest. Microbiol. 8:44-61.

Felis, G. E., R. Dellaglio, L. Mizzi, and S. Torriani. 2001. Comparative sequence analysis of a recA gene fragment brings new evidence for a change in the taxonomy of the Lactobacillus casei group. Int. J. Syst. Evol. Microbiol. 51:2113-2117.

Fenlon, D. R., and J. Wilson. 2000. Growth of Escherichia coli 0157 in poorly fermented laboratory silage: A possible environmental dimension in the epidemiology of E. coli O157. Lett. Appl. Microbiol. 30:118-121.

Filya, I. 2003. The effect of Lactobacillus buchneri and Lactobacillus plantarum on the fermentation, aerobic stability, and ruminal degradability of low dry matter corn and sorghum silages. J. Dairy Sci. 86:3575-3581

Frenzen, P. D., A. Drake, and F. J. Angulo. 2005. Economic cost of illness due to Escherichia coli O157 infections in the United States. J. Food Prot. 68:2623-2630.

Frey, K. G., J. E. Herrera-Galeano, C. L. Redden, T. V. Luu, S. L. Servetas, A. J. Mateczun, V. P. Mokashi, and K. A. Bishop-Lilly. 2014. Comparison of three next-generation sequencing platforms for metagenomic sequencing and identification of pathogens in blood. BMC Genomics 15:96-110.

Fuhs, G. W., and M. Chen. 1975. Microbiological basis of phosphate removal in the activated sludge process for treatment wastewater. Microb. Ecol. 2:119-138.

Fusco, V., G. M. Quero, G. S. Cho, J. Kabisch, D. Meske, H. Neve, H. Bockelmann, and C. M. A. P. Franz. 2015. The genus Weissella: Taxonomy, ecology and biotechnological potential. Front. Microbiol. 6:155.

Gollop, N., V. Zakin, and Z. G. Weinberg. 2005. Antibacterial activity of lactic acid bacteria included in inoculants for silage and in silages treated with these inoculants. J. Appl. Microbiol. 98:662-666.

Goodson, M., and R. J. Rowbury. 1989. Habituation to normally lethal acidity by prior growth of Escherichia coli at a sub-lethal acid $\mathrm{pH}$ value. Lett. Appl. Microbiol. 8:77-79.

Graf, K., A. Ulrich, C. Idler, and M. Klocke. 2016. Bacterial community dynamics during ensiling of perennial ryegrass at two compaction levels monitored by terminal restriction fragment length polymorphism. J. Appl. Microbiol. 120:1479-1491.

Hancock, D., T. Besser, J. Lejeune, M. Davis, and D. Rice. 2001. The control of VTEC in the animal reservoir. Int. J. Food Microbiol. 66:71-78.

Hanshew, A. S., C. J. Mason, K. F. Raffa, and C. R. Currie. 2013. Minimization of chloroplast contamination in $16 \mathrm{~S}$ rRNA gene pyrosequencing of insect herbivore bacterial communities. J. Microbiol. Methods 95:149-155.

Kämpfer, P., and S. P. Glaeser. 2012. Prokaryotic taxonomy in the sequencing era-The polyphasic approach revisited. Environ. Microbiol. 14:291-317.

Kaper, J. B., J. P. Nataro, and H. L. Mobley. 2004. Pathogenic Escherichia coli. Nat. Rev. Microbiol. 2:123-140.
Keen, J. E., and R. O. Elder. 2002. Isolation of Shiga-toxigenic Escherichia coli $\mathrm{O} 157$ from hide surfaces and the oral cavity of finished beef feedlot cattle. J. Am. Vet. Med. Assoc. 220:756-763.

Kleinschmit, D. H., and L. Kung Jr. 2006. A meta-analysis of the effects of Lactobacillus buchneri on the fermentation and aerobic stability of corn, grass and small grain silages. J. Dairy Sci. 89:4005-4013.

Kleinschmit, D. H., R. J. Schmidt, and L. Kung Jr. 2005. The effects of various antifungal additives on the fermentation and aerobic stability of corn silage. J. Dairy Sci. 88:2130-2139.

Klindworth, A., E. Pruesse, T. Schweer, J. Peplies, C. Quast, M. Horn and F. O. Glockner. 2013. Evaluation of general 16S ribosomal RNA gene PCR primers for classical and next-generation sequencing-based diversity studies. Nucleic Acids Res. 41:e1.

Kraut-Cohen, J., V. Tripathi, Y. Chen, J. Gatica, V. Volchinski, S. Sela, Z. Weinberg, and E. Cytryn. 2016. Temporal and spatial assessment of microbial communities in commercial silages from bunker silos. Appl. Microbiol. Biotechnol. 100:6827-6835.

Krooneman, J., F. Faber, A. C. Alderkamp, S. J. H. W. Oude Elferink, F. Driehuis, I. Cleenwerck, J. Swings, J. C. Gottschal, and M. Vancanneyt. 2002. Lactobacillus diolivorans sp. nov., a 1,2-propanediol-degrading bacterium isolated from aerobically stable maize silage. Int. J. Syst. Evol. Microbiol. 52:639-646.

Kung, L., Jr. 2010. Aerobic stability of silage. In Proceedings of California Alfalfa and Forage Symposium and Crop/Cereal Conference, Visalia, CA. Accessed Jul. 1, 2016. http://alfalfa.ucdavis. edu/+symposium/proceedings/2010/10-89.pdf.

Kung, L., Jr., and R. Shaver. 2001. Interpretation and use of silage fermentation analysis reports. Focus on Forage 3:1-5.

Kung, L., Jr., A. C. Sheperd, A. M. Smagala, K. M. Endres, C. A. Bessett, N. K. Ranjit, and J. L. Glancey. 1998. The effect of preservatives based on propionic acid on the fermentation and aerobic stability of corn silage and a total mixed ration. J. Dairy Sci. $81: 1322-1330$

Lahti, E., O. Ruoho, L. Rantala, M. L. Hanninen, and T. HonkanenBuzalski. 2003. Longitudinal study of Escherichia coli $\mathrm{O} 157$ in a cattle finishing unit. Appl. Environ. Microbiol. 69:554-561.

Leyer, G. J., L. Wang, and E. A. Johnson. 1995. Acid adaptation of Escherichia coli O157:H7 increases survival in acidic foods. Appl. Environ. Microbiol. 61:3752-3755.

Li, W., L. Fu, B. Niu, S. Wu, and J. Wooley. 2012. Ultrafast clustering algorithms for metagenomic sequence analysis. Brief. Bioinform. 13:656.

Li, Y., and N. Nishino. 2011. Effects of inoculation of Lactobacillus rhamnosus and Lactobacillus buchneri on fermentation, aerobic stability and microbial communities in whole crop corn silage. J. Jpn. Grassl. Sci. 57:184-191.

March, S. B., and S. Ratnam. 1989. Latex agglutination test for detection of Escherichia coli serotype O157. J. Clin. Microbiol. 27:16751677 .

Mead, P. S., L. Slutsker, V. Dietz, L. F. McCaig, J. S. Bresee, C. Shapiro, P. M. Griffin, and R. V. Tauxe. 1999. Food-related illness and death in the United States. Emerg. Infect. Dis. 5:607-625.

Mir, R. A., T. A. Weppelmann, M. Kang, T. M. Bliss, N. DiLorenzo, G. C. Lamb, S. Ahn, and K. C. Jeong. 2015. Association between animal age and the prevalence of Shiga toxin-producing Escherichia coli in a cohort of beef cattle. Vet. Microbiol. 175:325-331.

Muck, R. E., and B. J. Holmes. 2000. Factors affecting bunker silo densities. Appl. Eng. Agric. 16:613-619.

Ndagano, D., T. Lamoureux, C. Dortu, S. Vandermoten, and P. Thonart. 2011. Antifungal activity of 2 lactic acid bacteria of the Weissella genus isolated from food. J. Food Sci. 76:M305-M311.

Noel, R. J., and L. G. Hambleton. 1976. Collaborative study of a semiautomated method for determination of crude protein in animal feeds. J. Assoc. Off. Anal. Chem. 59:134-140.

Ogunade, I. M., D. H. Kim, Y. Jiang, Z. G. Weinberg, K. C. Jeong, and A. T. Adesogan. 2016. Control of Escherichia coli O157:H7 in alfalfa silage contaminated with the pathogen: Effects of silage additives. J. Dairy Sci. 99:4427-4436.

Oude Elferink, S. J. W. H., J. Krooneman, J. C. Gottschal, S. F. Spoelstra, F. Faber, and F. Driehuis. 2001. Anaerobic conversion 
of lactic acid to acetic acid and 1, 2-propanediol by Lactobacillus buchneri. Appl. Environ. Microbiol. 67:125-132.

Pahlow, G., R. E. Muck, F. Driehuis, S. J. W. H. Oude Elferink, and S. F. Spoelstra. 2003. Microbiology of ensiling. Pages 31-93 in Silage Science and Technology. D. R. Buxton, R. E. Muck, and J. H. Harrison, ed. American Society of Agronomy, Inc., Crop Science Society of America Inc., Soil Science Society of America Inc. Publications, Madison, WI.

Pang, H., G. Qin, Z. Tan, Z. Li, Y. Wang, and Y. Cai. 2011. Natural populations of lactic acid bacteria associated with silage fermentation as determined by phenotype, $16 \mathrm{~S}$ ribosomal RNA and recA gene analysis. Syst. Appl. Microbiol. 34:235-241.

Park, S. H., S. I. Lee, and S. C. Ricke. 2016. Microbial populations in naked neck chicken ceca raised on pasture flock fed with commercial yeast cell wall prebiotics via an Illumina MiSeq Platform. PLoS One 11:e0151944.

Pedroso, A. F., A. T. Adesogan, O. C. M. Queiroz, and S. Williams. 2010. Control of Escherichia coli O157:H7 in corn silage with or without various inoculants: Efficacy and mode of action. J. Dairy Sci. 93:1098-1104.

Pitt, R. E. 1986. Dry matter losses due to oxygen infiltration into silos. J. Agric. Eng. Res. 35:193-205.

Polley, H. W., B. J. Wilsey, and J. D. Derner. 2007. Dominant species constrain effects of species diversity on temporal variability in biomass production of tallgrass prairie. Oikos 116:2044-2052.

Quail, M. A., M. Smith, P. Coupland, T. D. Otto, S. R. Harris, T. R. Connor, A. Bertoni, H. P. Swerdlow, and Y. Gu. 2012. A tale of three next generation sequencing platforms: comparison of Ion Torrent, Pacific Biosciences and Illumina MiSeq sequencers. BMC Genomics 13:341-354.

Queiroz, O. C. M., K. G. Arriola, J. L. P. Daniel, and A. T. Adesogan. 2013. Effects of 8 chemical and bacterial additives on the quality of corn silage. J. Dairy Sci. 96:5836-5843.

Ranjit, N. K., C. C. Taylor, and L. Kung Jr. 2002. Effect of Lactobacillus buchneri 40788 on the fermentation, aerobic stability and nutritive value of maize silage. Grass Forage Sci. 57:73-81.

Reinstein, S., J. T. Fox, X. Shi, and T. G. Nagaraja. 2007. Prevalence of Escherichia coli O157:H7 in gallbladders of beef cattle. Appl. Environ. Microbiol. 73:1002-1004.

Russell, J. B., F. Diez-Gonzalez, and G. N. Jarvis. 2000. Potential effects of cattle diets on the transmission of pathogenic Escherichia coli to humans. Microbes Infect. 2:45-53.

Santos, A. O., C. L. S. Avila, J. C. Pinto, B. F. Carvalho, D. R Dias, and R. F. Schwan. 2016. Fermentative profile and bacterial diversity of corn silages inoculated with new tropical lactic acid bacteria. J. Appl. Microbiol. 120:266-279.

Satoh, H., W. D. Ramey, F. A. Koch, W. K. Oldham, T. Mino, and T. Matsuo. 1996. Anaerobic substrate uptake by the enhanced bio- logical phosphorus removal activated sludge treating real sewage. Water Sci. Technol. 34:8-15.

Scallan, E., R. M. Hoekstra, F. J. Angulo, R. V. Tauxe, M. A. Widdowson, and S. L. Roy. 2011. Foodborne illness acquired in the United States-Major pathogens. Emerg. Infect. Dis. 17:7-15.

Schmidt, R. J., and L. Kung Jr. 2010. The effects of Lactobacillus buchneri with or without a homolactic bacterium on the fermentation and aerobic stability of corn silages made at different locations. J. Dairy Sci. 93:1616-1624.

Smith, D. R., R. A. Moxley, S. L. Clowser, J. D. Folmer, S. Hinkley, G. E. Erickson, and T. J. Klopfenstein. 2005. Use of rope devices to describe and explain the feedlot ecology of Escherichia coli O157:H7 by time and place. Foodborne Pathog. Dis. 2:50-60.

Stevenson, D. M., R. E. Muck, K. J. Shinners, and P. J. Weimer 2006. Use of real time PCR to determine population profiles of individual species of lactic acid bacteria in alfalfa silage and stored corn stover. Appl. Microbiol. Biotechnol. 71:329-338.

Torriani, S., G. E. Felis, and F. Dellaglio. 2001. Differentiation of Lactobacillus plantarum, L. pentosus, and L. paraplantarum by recA gene sequence analysis and multiplex PCR assay with recA genederived primers. Appl. Environ. Microbiol. 67:3450-3454.

Van Soest, P. J., J. B. Robertson, and B. A. Lewis. 1991. Methods for dietary fiber, neutral detergent fiber and non-starch polysaccharides in relation to animal nutrition. J. Dairy Sci. 74:3583-3597.

Ward, R. T. 2008. Fermentation analysis of silage: Use and interpretation. Accessed Jul. 1, 2016. http://www.foragelab.com/media/ fermentation-silage-nfmp-oct-2008.

Weinberg, Z. G., G. Ashbell, Y. Hen, and A. Azrieli. 1995. The effect of propionic acid bacterial inoculant applied at ensiling on the aerobic stability of wheat and sorghum silages. J. Ind. Microbiol. Biotechnol. 15:493-497.

Woolford, M. K. 1975. Microbial screening of food preservatives, cold sterilants, and specific antimicrobial agents as potential silage additives. J. Sci. Food Agric. 26:229-237.

Wu, J. J., R. P. Du, M. Gao, Y. Q. Sui, L. Xiu, and X. Wang. 2014. Naturally occurring lactic acid bacteria isolated from tomato pomace silage. Asian-australas. J. Anim. Sci. 27:648-657.

Zadik, P. M., P. A. Chapman, and C. A. Siddons. 1993. Use of tellurite for the selection of verocytotoxigenic Escherichia coli O157. J. Med. Microbiol. 39:155-158.

Zhang, C., M. J. Brandt, C. Schwab, and M. G. Gänzle. 2010. Propionic acid production by cofermentation of Lactobacillus buchneri and Lactobacillus diolivorans in sourdough. Food Microbiol. 27:390-395.

Zhang, W., Z. Sun, B. Menghe, and H. Zhang. 2015. Short communication: Single molecule, real-time sequencing technology revealed species- and strain-specific methylation patterns of 2 Lactobacillus strains. J. Dairy Sci. 98:3020-3024. 